\title{
Food insecurity during the COVID-19 pandemic: evidence from a survey of low-income Americans
}

\author{
Di Fang ${ }^{1}$ (D) Michael R. Thomsen ${ }^{2} \cdot$ Rodolfo M. Nayga Jr. $^{3} \cdot$ Wei Yang $^{1}$
}

Received: 17 December 2020 / Accepted: 15 June 2021 / Published online: 7 July 2021

(C) International Society for Plant Pathology and Springer Nature B.V. 2021

\begin{abstract}
The COVID-19 pandemic significantly increased food insecurity despite emergency legislation that put more resources into food assistance programs, increased unemployment benefits, and provided stimulus payments. We conducted a survey in the US on food insecurity among low-income Americans during the early months of the pandemic. While we cannot estimate causal effects, we are able to show important associations between food insecurity and nutritional and economic assistance that highlight the need to ensure that those newly at risk for food insecurity are able to connect to resources. For example, our results indicate that those who lost jobs due to the pandemic reported the highest level of food insecurity and also the lowest engagement with food assistance programs. The SNAP expansion appears to be important only among groups with higher levels of income stability including non-minority households and those not experiencing a job loss. Thus, the SNAP expansion may not have had a meaningful impact on those most at risk for food insecurity. Finally, our data highlight the importance of school meal programs during normal times. Those who took advantage of school meals before the outbreak are more likely to have experienced food insecurity during the pandemic-related school closures.
\end{abstract}

Keywords Food insecurity $\cdot$ COVID-19 pandemic $\cdot$ Low-income $\cdot$ Racial disparity

JEL classification $\mathrm{C} 31 \cdot \mathrm{I} 14 \cdot \mathrm{Q} 18$

\section{Introduction}

The COVID-19 pandemic has created unprecedented challenges. With the pandemic-induced economic downturn, limited public transportation, and disruptions to the food system, low-income families now face adverse situations that can have significant consequences for food security. Federal nutrition assistance programs play an important role in sustaining food security in times of economic downturn (Bitler \& Hoynes, 2016). The Supplemental Nutrition Assistance Program

Di Fang

difang@uark.edu

1 Department of Agricultural Economics and Agribusiness, University of Arkansas, Fayetteville, AR, USA

2 Fay W. Boozman College of Public Health, University of Arkansas for Medical Sciences, Little Rock, AR, USA

3 Department of Agricultural Economics, Texas A\&M University, College Station, TX, USA
(SNAP), being the largest nutritional assistance program in the US, served approximately 20.9 million household with an average benefit of $\$ 254$ per household per month in 2019 (USDA-FNS, 2020a). In response to the food security crisis, the Families First Coronavirus Act (FFCA) increased SNAP benefit allotments up to the maximum allowable amount as an emergency measure in many states (US Department of Labor, 2020). FFCA also enabled states to issue pandemic electronic meal-replacement benefits, or pandemic Electronic Benefits Transfer (EBT), for households with children eligible to receive free or reduced-price school meals, equivalent to roughly $\$ 114$ per child a month (USDA-FNS, 2020b). ${ }^{1}$

More than 7 million (roughly $40 \%$ of all SNAP) households already received the maximum benefits (Rosenbaum et al., 2020), therefore under the emergency allotments of FFCA, they received no extra aid from SNAP. On the other

\footnotetext{
${ }^{1}$ Provisions also included streamlining the application process and reducing administrative hurdles by permitting telephonic signatures and waiving the application interview. These options allowed states to better manage increased caseloads to meet the increase in food assistance needs (Rosenbaum et al., 2020).
} 
hand, increasing benefits alone may not be enough to address the barriers low-income families are facing in acquiring food during the pandemic. Even with the larger benefit per the FFCA, SNAP dollars are unlikely to last throughout the entire monthly benefit period (Wilde \& Ranney, 2000; Cotti et al., 2020; Gregory \& Todd, 2021). Additionally, stockpiling behavior could worsen the situation for low-income families who cannot afford to buy in bulk. For families who rely on The Special Supplemental Nutrition Program for Women, Infants, and Children (WIC), the food security status is even worse because WIC benefits are restricted to certain food items and can only be redeemed at stores that accept the benefits (USDA-FNS, 2020c).

The objective of this paper is to understand how federal food assistance programs (SNAP, WIC, and school food programs) have helped alleviate food insecurity among lowincome individuals during the pandemic. We also investigate the differential associations of these programs with food insecurity by race or ethnicity, families with children, and families that experienced job loss due to COVID-19. To meet this objective, we conducted a nationwide survey in June and July of 2020 targeting adults with incomes less than 200\% of the Federal Poverty Line (FPL). The survey addressed household food security status, participation in federal and local assistance programs, financial hardships related to COVID-19, food access during the pandemic, food shopping behaviors, and demographic information.

Our results indicate that losing a job due to the pandemic was associated with the highest level of food insecurity but was weakly associated with food assistance programs. Pandemic related job loss was highly associated with the receipt of unemployment benefits, something most newly unemployed would know are available to them. Hence, food assistance programs may not be reaching those who have great need but little prior experience with food benefits. Our results also show a negative association between food insecurity and SNAP benefit expansion among groups with higher levels of income stability including non-minority households and those not experiencing a job loss. Because the benefit expansion could only help those who were not already receiving the maximum SNAP benefit, it may not have had a meaningful impact on those at greatest risk for food insecurity. Our results also indicate that those who took advantage of school meals before the outbreak are more likely to have experienced food insecurity after the pandemic-related school closures. Short term solutions such as the Pandemic EBT program could significantly decrease the likelihood of food insecurity among the lowest-income respondents with children.

The paper proceeds as follows. The next section discusses the background of this study, followed by a discussion of the survey and a section of descriptive statistics. We then outline the econometric analysis and present the results. A final section concludes and discusses the findings.

\section{Background}

More than 37 million people were food insecure before the pandemic Coleman-Jensen et al. (2019). These numbers reflect a historically low point since the Great Recession. However, with the pandemic-induced economic downturn, limited public transportation, and disruptions to the food system, low-income families now face adverse situations that can have significant consequences for food security. At the beginning of the pandemic, many households stockpiled shelfstable foods (Information Resources, Inc., 2020), causing low-income households to visit multiple food stores to search for the most affordable products. Poor families often travel long distances to acquire food and rely heavily on public transit (Cannuscio et al., 2013). Moreover, with schools being closed and families out of work, children in lower-income households are at higher risk of being food insecure (Dunn et al., 2020).

On March 27 of 2020, the Coronavirus Aid, Relief, and Economic Security (CARES) Act was passed as a response to the economic damage caused by the virus (US Department of the Treasury, 2020). The over $\$ 2$ trillion economic relief package included one-time stimulus payments generally consist of $\$ 1200$ per adult and an additional $\$ 500$ for each child under 17 years old, depending on household income. Besides the stimulus payments, 30 million unemployed workers received $\$ 600$ in addition to an unemployed worker's regular weekly benefit (Stone, 2020). Raifman et al. (2021) found that the receiving unemployment insurance to be associated with large reductions in food insecurity among people who lost employment during the pandemic.

The CARES Act included a $\$ 15.8$ billion appropriation for SNAP and $\$ 8.8$ billion for child nutrition programs. SNAP is an entitlement program that places few limits on allowable purchases. By design, SNAP responds quickly to increased need due to job loss or other economic shocks (Bitler et al., 2020). As previously mentioned, SNAP families were able to receive additional benefits (up to the maximum SNAP benefit) during the pandemic. Because SNAP benefits normally decline as income rises, SNAP recipients with higher incomes were more likely to realize an increase in benefits under the FCCA provisions. The CARES Act also provided $\$ 500$ million to WIC to be allocated to all WIC state agencies. To adhere to social distancing guidelines, the Act waived the requirement for individuals seeking WIC certification to visit WIC clinics in person (USDA-FNS, 2020c). An earlier report indicates that the availability of WIC foods in WIC approved retail stores was deemed to be a barrier to effectively using WIC during the pandemic (Grose, 2020).

Before the pandemic, nearly 35 million children benefited daily from the federal school meal programs (USDA-FNS, 2020b). With school closures, there was no federal mandate that schools should offer meal service. However, under the 
FFCA, state agencies were allowed to disburse EBT benefits for children who qualify for free or reduced-price meals via the Pandemic EBT program (Dunn et al., 2020). Some districts continued meal delivery or pickup during pandemicrelated school closures. Schools could temporarily waive meal time requirements to make it easier to pick up meals for multiple-days. The Act also allowed states, on an individual stateby-state basis, to serve free meals to children in all schools (US Department of Labor, 2020).

The outbreak of the coronavirus at food processing plants affected the food supply (Gallagher \& Kirkland, 2020). As a result, consumers saw an increase in retail food prices in April, led by meats and eggs (Johansson, 2020). In the meantime, the demand for food remained high after peaking in March (Information Resources, Inc., 2020). Although the food supply seemed to remain robust (Johansson, 2020), consumers saw empty shelves because of the elevated demand for staple goods, supply chain challenges, and stockpiling behaviors (Information Resources, Inc., 2020). Families living in neighborhoods with limited access to grocery stores, e.g., food deserts, may have experienced additional difficulties due to business closures and modifications to transit services (Siddiqi et al., 2020). Empty shelves may be especially harmful to families who rely on WIC, which limits benefits to specific foods, as was already documented in (Grose, 2020).

Another way that households were able to maintain adequate access to food was through online shopping (Chang \& Meyerhoefer, 2020; Reardon et al., 2021). Redman (2020) reported that Walmart's online grocery sales increased $74 \%$ in April. However, online shopping may not be feasible for some SNAP recipients. At the beginning of the pandemic, low-income SNAP recipients were prohibited from using their benefits to purchase foods online. Therefore, many SNAP recipients could not order groceries to be delivered and were thus required to shop in-person, thereby putting themselves and their families at greater risk and furthering accentuating income disparities in the effects of COVID-19 (Rosenbaum et al., 2020). This is now changing through the SNAP Online Purchasing Pilot program (USDA-FNS, 2020d). However, the pilots are limited to selected retailers in participating states. Therefore, many recipients may not benefit from online purchases due to availability as well as differences in timing of program roll-out (Rosenbaum et al., 2020).

\subsection{The survey}

We designed a web-based survey targeting low-income adults in the US. The survey was distributed to respondents using Dynata, an online platform. Dynata also allows researchers to screen respondents based on an income criterion.. In our study, we limited the sample to low-income adults in households at or below the $200 \%$ the FPL. Regular federal SNAP rules require families with no elderly or disabled members to have gross income below 130\% FPL. However, the "broadbased categorical eligibility" lets states import up to $200 \%$ FPL given TANF-funded program (USDA FNS, 2020a). Respondents from households who reported an income higher than $200 \%$ of the FPL were excluded from this study. ${ }^{2}$

We modified the 10-item US Adult Food Security Survey Module (USDA-FNS, 2020e) to elicit information about respondents' food insecurity status during the past 90 days. While the module has been validated for one month and one year, it has not specifically been validated for three months. Given the timing of the survey, we assessed three months to best capture the respondents experience since the beginning of the pandemic. This module is comprised of indicator questions that capture and distinguish the severity of food insecurity. Questions are ordered by severity and include three levels of screening for adults. The USDA divides households into the following categories: high food secure (all household members had access at all times to enough food for an active, healthy life), marginal food secure (some members reported anxiety about food sufficiency or shortage of food in the house), low food secure (at least some household members reported reduced quality, variety), and very low food secure (one or more household members reported multiple indications of disrupted eating patterns and reduced food intake) (Gundersen \& Ziliak, 2015). Affirmative responses to questions were summed to one of the following four categories: high food secure (no affirmative responses), marginal food secure (1-2 affirmative responses), low food secure (3-5 affirmative responses), and very low food secure (6 or more affirmative responses). For purposes of this study, respondents in the low and very low food secure categories were considered to be food insecure (USDA-FNS, 2020e).

In this survey, we inquired about SNAP participation. Specifically, we first asked whether the household ever received SNAP and then followed up by asking when SNAP was last received. The monthly SNAP benefit amount received before the pandemic, whether additional SNAP benefits were received and the amount of additional SNAP benefits. We also asked questions on how easy the respondent could access SNAP and whether they had trouble receiving SNAP remotely during the pandemic. WIC participation, remote benefit collection, and whether the respondent was able to find WIC foods in stores were also included in the survey. In addition, we inquired about school meal participation in 2019, alternative meals provided by schools during the pandemic, and how frequently alternative school meals were utilized.

The survey also investigated whether someone in the household lost his/her job due to the pandemic. If the answer was affirmative, we then asked whether the respondent had

\footnotetext{
${ }^{2}$ For example, $\$ 52,400$ would place a four-person household at $200 \%$ of the FPL in 2020 .
} 
received unemployment benefits. Food availability was inquired on whether or not the respondent switched stores due to unavailability, whether price increases were observed, and whether online grocery purchases were an option. If the respondent indicated switching stores due to unavailability of foods, additional questions were asked about food availability, whether price increases were observed, and whether online grocery purchases were an option. The food desert status of the respondent was determined by linking the geographic coordinates based on the respondent's IP address to the census tract, which is the geographic unit available in the USDA's Food Environment Atlas data (Food Environment Atlas, 2020). Finally, a set of socio-demographic questions concluded the survey.

\subsection{Descriptive statistics}

The survey was conducted from June 29, 2020 to July 21, 2020. The number of income-eligible individuals completing the survey was 2772 . Some participants were excluded due to inconsistent reporting of ZIP Code. To ensure data integrity, we also restricted our sample based on the following criterion: 1) age under 100 years old; 2) a maximum household size of 10;3) maximum SNAP benefit given household size; 4) maximum stimulus payment given marital status and number of children; and 5) driving time to secure groceries of under an hour. This sample drew respondents from all 50 states plus the District of Columbia. Hence, our analysis sample consists of 2714 observations.

As explained above, we measured the four levels of food insecurity based on the USDA's guideline from the 10-item food security component of the survey (USDAFNS, 2020e). Table 1 characterizes our sample in terms of these four levels. Overall, $48.4 \%$ of this sample was food secure and 51.6\% were food insecure. As noted above, respondents were classified as "food insecure" if they fell into the low (17.39\%) or very low $(34.23 \%)$ food security categories. Food insecurity in 2019 among households below the 185 FPL was $28 \%$ (USDA-ERS, 2020) so incidence in our sample is much larger than this national figure. Some of this difference is likely due to economic hardship brought on by the pandemic, but it is also important to keep in mind that our survey asked about food insecurity in the last three months as opposed to the last month.

Table 1 also presents $p$-values from tests to examine heterogeneity in selected variables with respect to food security status. Results show there were significant differences between food insecure and food secure respondents in terms of federal and local nutrition programs, stimulus payments, unemployment benefits, pandemic related job loss, income stability, number of children, the ability to purchase groceries online, observed food price increases, and driving time to the store. There were also significant differences by race and ethnicity. Food desert status, residential population, urbanity, and marital status, however, did not differ significantly by food security status.

Based on the findings in Table 1, we created eight subsamples: 1) a SNAP eligible sample based on income; 2) households with children; 3 ) households without children; 4) households experiencing a pandemic-related job loss; 5) households who did not experience a pandemic-related job loss; 6) African American households; 7) Hispanic households; and 8) Caucasian households.

Approximately $45 \%$ of the full sample $(n=1214)$ reported being on SNAP, with an average monthly benefit of \$241.6. The average SNAP benefit is for all those received SNAP. However, the expansion (or additional SNAP) is only for those who were not already at their maximum. Among the SNAP recipients, only $10.2 \%$ reported receiving additional SNAP benefits with an average additional benefit of $\$ 101.8$. Because SNAP is an entitlement program for those who are income eligible, we constructed the SNAP eligible sample based on income (i.e., under $130 \%$ of the FPL). Since income was reported as a category in our survey, we calculated the upper and lower bounds of SNAP eligible income based on household size. We then assigned respondents to be ineligible, definitely eligible, and possibly eligible depending on where they fell within the category. The SNAP-eligible sample consists of only the 1177 respondents who were definitely eligible.

\subsection{Statistical analysis}

To explore the associations between food insecurity and food assistance programs during the pandemic, we estimated structural equation models (SEM). ${ }^{3}$ The dependent variable is the binary food insecurity variable which is estimated simultaneously with program participation in SNAP, WIC, school meals, receipt of alternative school meals, and the receipt of community foods. Specifically, we additionally estimate equations for SNAP, WIC, School Meals, and Community Foods. Each of these equations includes food insecurity as a regressor along with all other covariates. The motivation for estimating the equations in a system is to correct for correlated and unobserved effects in the errors (Greene, 2008) that could jointly determine food insecurity and program participation. We do not claim causal inference from the SEM estimates. However, the estimation should provide more accurate associations than single-equation linear probability or logit

\footnotetext{
${ }^{3}$ It is well documented that the selection issue makes it difficult to identify a causal relationship between SNAP participation and food insecurity (Ratcliffe \& McKernan, 2010). Past literature has employed instrumental variables (IV) to attempt to tease out the causal effects. Common IVs for SNAP participation include state variation in eligibility (Bartfeld \& Dunifon, 2006; Ratcliffe \& McKernan, 2010). However, this is not applicable because COVID-related SNAP expansion has completed for almost all States by the time of survey.
} 
Table 1 Food Security Status

\begin{tabular}{|c|c|c|c|c|c|c|}
\hline & All & High Security & Marginal Security & Low Security & Very low Security & \\
\hline & $\mathrm{N}(\%)$ & $\mathrm{N}(\%)$ & $\mathrm{N}(\%)$ & $\mathrm{N}(\%)$ & $\mathrm{N}(\%)$ & $p$ value \\
\hline Total & $2714(100)$ & $866(31.91)$ & $447(16.47)$ & $472(17.39)$ & $929(34.23)$ & \\
\hline $\begin{array}{l}\text { SNAP } \\
\text { Yes }\end{array}$ & $1214(45)$ & $280(23.06)$ & $188(15.49)$ & $235(19.36)$ & $511(42.09)$ & $<0.001$ \\
\hline No & $1500(55)$ & $586(39.07)$ & $259(17.27)$ & $237(15.8)$ & $418(27.87)$ & \\
\hline \multicolumn{7}{|c|}{ Additional SNAP } \\
\hline Yes & $662(24)$ & $157(23.72)$ & $104(15.71)$ & $138(20.85)$ & 263(39.73) & \multirow[t]{2}{*}{$<0.001$} \\
\hline No & $2052(76)$ & $709(34.55)$ & $343(16.72)$ & $334(16.28)$ & $666(32.46)$ & \\
\hline \multicolumn{7}{|l|}{ WIC } \\
\hline Yes & $249(9)$ & $33(13.25)$ & $24(9.64)$ & $48(19.28)$ & $144(57.83)$ & \multirow[t]{2}{*}{$<0.001$} \\
\hline No & $2465(91)$ & $833(33.79)$ & $423(17.16)$ & $424(17.2)$ & $785(31.85)$ & \\
\hline \multicolumn{7}{|c|}{ School Meals } \\
\hline Yes & $533(20)$ & $60(11.26)$ & 71(13.32) & $102(19.14)$ & $300(56.29)$ & \multirow[t]{2}{*}{$<0.001$} \\
\hline No & $2181(80)$ & $806(36.96)$ & $376(17.24)$ & $370(16.96)$ & $629(28.84)$ & \\
\hline \multicolumn{7}{|c|}{ Alternative School Meals } \\
\hline Yes & $453(17)$ & $52(11.48)$ & $57(12.58)$ & $82(18.1)$ & $262(57.84)$ & \multirow[t]{2}{*}{$<0.001$} \\
\hline No & $2261(83)$ & $814(36)$ & $390(17.25)$ & $390(17.25)$ & $667(29.5)$ & \\
\hline \multicolumn{7}{|c|}{ Charitable Foods } \\
\hline Yes & $839(31)$ & $132(15.73)$ & 109(12.99) & $144(17.16)$ & $454(54.11)$ & \multirow[t]{2}{*}{$<0.001$} \\
\hline No & $1875(69)$ & $734(39.15)$ & $338(18.03)$ & $328(17.49)$ & $475(25.33)$ & \\
\hline \multicolumn{7}{|c|}{ Lost Job } \\
\hline Yes & $534(20)$ & $77(14.42)$ & $46(8.61)$ & $96(17.98)$ & $315(58.99)$ & \multirow[t]{2}{*}{$<0.001$} \\
\hline No & $2180(80)$ & $789(36.19)$ & 401(18.39) & $376(17.25)$ & $614(28.17)$ & \\
\hline \multicolumn{7}{|c|}{ Received UI } \\
\hline Yes & $276(10)$ & $68(24.64)$ & $42(15.22)$ & $53(19.2)$ & $113(40.94)$ & \multirow[t]{2}{*}{0.019} \\
\hline No & $2438(90)$ & $798(32.73)$ & $405(16.61)$ & $419(17.19)$ & $816(33.47)$ & \\
\hline \multicolumn{7}{|c|}{ Received Stimulus } \\
\hline Yes & 1997(74) & $719(36)$ & $328(16.42)$ & $314(15.72)$ & $636(31.85)$ & \multirow[t]{2}{*}{$<0.001$} \\
\hline No & $717(26)$ & $147(20.5)$ & $119(16.6)$ & $158(22.04)$ & $293(40.86)$ & \\
\hline \multicolumn{7}{|c|}{ Online Shopping } \\
\hline Yes & $940(35)$ & $258(27.45)$ & $143(15.21)$ & $154(16.38)$ & $385(40.96)$ & \multirow[t]{2}{*}{$<0.001$} \\
\hline No & $1774(65)$ & $608(34.27)$ & $304(17.14)$ & $318(17.93)$ & $544(30.67)$ & \\
\hline \multicolumn{7}{|c|}{ Food Dessert } \\
\hline Yes & $374(14)$ & $118(31.55)$ & $62(16.58)$ & $61(16.31)$ & $133(35.56)$ & \multirow[t]{2}{*}{0.904} \\
\hline No & $2332(86)$ & $747(32.03)$ & $383(16.42)$ & $410(17.58)$ & $792(33.96)$ & \\
\hline
\end{tabular}

Note: $p$ values indicate the $x^{2}$ test between subsample who answered "Yes" and those who answered "No"

models. We did not include state fixed effects in these models because we only have a few observations in certain states, hence including state fixed effects will introduce singularity in the subsamples. Also, the lockdown policies were generally mild during the sampling period, so that the different states are more or less comparable. The system is estimated using a generalized least square estimator (GLS) and estimates are produced by the systemfit package in R (Henningsen et al., 2007).

\section{Results}

As shown in Table 2, the average food insecurity score is higher (meaning more food insecure) in the SNAP eligible sample, with $61.4 \%$ of respondents being food insecure, compared to $51.6 \%$ in the overall sample. Among SNAP eligible respondents, we also observe a higher percentage of participation in other food assistance programs, namely WIC, school meals, alternative school meals during the pandemic, and charitable food programs. About $22.3 \%$ of the respondents in the SNAP-eligible sample reported pandemic related job loss, compared to $19.7 \%$ in the overall sample. However, the percentage receiving unemployment benefits is comparable. Food access variables are comparable between the SNAP sample and the overall sample with similar statistics on distance to store, the ability to shop online, and food desert status. The SNAP sample has a higher proportion of Black and Hispanic respondents compared to the overall sample, consistent with national statistics (USDA-ERS, 2020). Overall, our data show that the SNAP sample is of lower-income and less financially secure.

We also compare households who lost jobs due to the pandemic to those who did not. About $19.7 \%(n=534)$ reported unemployment due to the pandemic. Food insecurity is much higher for the unemployed sample, with $77 \%$ being food insecure compared to $45.4 \%$ in the employed sample. Among those who lost jobs, $31.3 \%$ received unemployment benefits. The unemployed sample reported a lower level of income stability (40.4\%) compared to the employed sample (69\%). 
They also reported a higher level of SNAP participation than those who were employed, consistent with the finding of (Bitler et al., 2020). Those who lost jobs were younger in age (36.4 years old compared to 49.3 years) and were less educated. This is consistent with the notion that most layoffs are temporary jobs assumed by lower-skilled or less experienced workers (Ganong et al., 2020). There was also a higher proportion of respondents reporting one or more children among the unemployed sample. This could be due to the fact that people had to leave jobs to take care of children when schools closed due to the pandemic.

Table 2 also compares respondents with children to those without. Approximately $32.7 \%$ of our sample $(n=887)$ had children, with an average of 1.8 children per household. Food insecurity was higher among respondents with children compared to those without (67\% compared to $44.2 \%$ ). Respondents with children also reported a much higher participation in SNAP, WIC, and school meals, consistent with the national averages (USDA-FNS, 2020a; USDA-FNS, 2020c). Respondents with children also reported a higher utilization of charitable foods compared to those without children. In our sample, households with children are less income stable (48.4\%, compared to $70.7 \%$ ) and as noted above were more likely to be unemployed (29.7\% compared to $14.8 \%$ ). The proportion of Hispanics is higher among the subsample with children.

Finally, we also examined whether there is racial disparity in our sample in terms of food insecurity. Table 2 shows the subsamples of Blacks, Hispanics, and Whites. Food insecurity is highest among the Hispanic sample (57.4\%) and lowest in the White sample (46.2\%). The Black sample reported the highest SNAP participation at $50.6 \%$, followed by Whites $(42.8 \%)$ and then Hispanics $(41.5 \%)$. WIC participation and pre-pandemic participation in school meals, post-pandemic participation in alternative school meal delivery programs, and use of charitable food assistance was also higher among respondents in the Black sample. Our data show that Blacks and Hispanics were less income stable, $58.6 \%$ and $52.8 \%$ respectively, compared to Whites at $73.9 \%$. However, $81.2 \%$ of Whites received the stimulus payment, whereas only $69.5 \%$ of Blacks and $65.8 \%$ of Hispanics did. Nichols and Simms (2012) argues that after adjusting for education, past employment, and reasons for unemployment, Black and Hispanic workers are significantly less likely to receive unemployment benefits than their White counterparts. This is not the case in our sample. Our sample reflected higher utilization of unemployment benefits among Blacks (11.9\%) and Hispanics (14.4\%) than Whites (6.5\%), which suggests COVIDrelated job losses disproportionately impacted minorities in our sample. We also note that $17.8 \%$ of Blacks reside in a food desert, compared to $13.9 \%$ for White and $9 \%$ for Hispanics.
Results for the SEM are presented in Table 3. Appendix Tables 4 and 5 present estimates from the single equation models: linear probability models and logit models, respectively for interested readers. Estimates from the single equation models presented in the appendix were similar results in terms of sign and significance. To facilitate comparison across the SEM and single-equation model specifications, key associations are reported as marginal effects in Appendix Figs. 1 to 9.

\subsection{SNAP and WIC}

Given the recent onset of the pandemic, the loss of a job may have been a large enough disruption to induce food insecurity regardless of the respondents' prior SNAP status. It is also possible that recently unemployed who were newly eligible for SNAP had not yet received benefits. The association between receipt of additional SNAP benefits and food insecurity is also negative but is less consistent across the different subsamples.

The association between receipt of additional SNAP benefits and food insecurity is statistically different from zero in the full sample and is particularly strong among households with children and may reflect additional benefits via the Pandemic EBT. Interestingly, there is no significant association between additional SNAP benefits and food insecurity among the SNAP-eligible sample. Because membership in this sample is contingent on income, it is possible that many SNAP recipients in this subsample were already near the maximum SNAP benefit allotment and hence were not meaningfully impacted by the additional SNAP benefits provided by the emergency COVID-19 legislation.

Finally, WIC participation is not strongly associated with food insecurity in our data. As in the case of participation in SNAP or community food programs, there could be bidirectionality in this association wherein eligible foodinsecure households are more likely to enroll in WIC. Evidence of this is provided by the strong positive association between WIC participation and food insecurity within the Hispanic subsample. Historically, Hispanic participation and coverage rates have exceeded other ethnic groups (USDAERS, 2020).

\subsection{School meals}

School meals are positively associated with food insecurity in the full sample and across most subsamples. Recall that school meals is measured as an indicator of whether anyone in the household received school meals during 2019, a period unaffected by the pandemic. Hence, the positive association is consistent with the loss of school meals during the pandemic contributing to higher food insecurity. This association is particularly strong and significant among the SNAP-eligible 
Table 2 Descriptive Statistics

Full Sample $(N=2714)$

Variables

SNAP

Additional SNAP

WIC

School Meals

Alternative School Meals

Charitable Foods

Lost Job

Income Stable

Unemployment Benefit

Receive Stimulus

Online Shopping

Food Dessert

Female

Age

Married

Black

Hispanic

White

College and Higher

High School

Less High School

Some College

Less $\$ 15,000$

\$15,000-\$29,999

$\$ 30,000-\$ 44,999$

$\$ 45,000$ and Above

$\begin{array}{ll} & \text { SNAP Eligible } \\ \text { Sample Size } & 1177 \\ & \text { mean } \\ \text { Food Insecurity (binary) } & 0.614 \\ \text { SNAP } & 0.569 \\ \text { Additional SNAP } & 0.304 \\ \text { WIC } & 0.118 \\ \text { School Meals } & 0.223 \\ \text { Alternative School Meals } & 0.198 \\ \text { Charitable Foods } & 0.359 \\ \text { Lost Job } & 0.223 \\ \text { Income Stable } & 0.572 \\ \text { Unemployment Benefit } & 0.103 \\ \text { Receive Stimulus } & 0.667 \\ \text { Online Shopping } & 0.336 \\ \text { Food Dessert } & 0.144 \\ \text { Female } & 0.744 \\ \text { Age } & 42.661 \\ \text { Married } & 0.163 \\ \text { Black } & 0.351\end{array}$

$\begin{array}{llllll} & \text { Lost Job } & & \text { Has Job } & & \text { With Childre } \\ & 534 & & 2180 & & 887 \\ \text { s.d. } & \text { mean } & \text { s.d. } & \text { mean } & \text { s.d. } & \text { mean } \\ 0.487 & 0.770 & 0.421 & 0.454 & 0.498 & 0.670 \\ 0.495 & 0.536 & 0.499 & 0.426 & 0.495 & 0.563 \\ 0.460 & 0.281 & 0.450 & 0.235 & 0.424 & 0.337 \\ 0.323 & 0.187 & 0.390 & 0.068 & 0.252 & 0.218 \\ 0.416 & 0.350 & 0.477 & 0.159 & 0.365 & 0.479 \\ 0.399 & 0.309 & 0.463 & 0.132 & 0.339 & 0.409 \\ 0.480 & 0.457 & 0.499 & 0.273 & 0.446 & 0.384 \\ 0.417 & & & & & 0.297 \\ 0.495 & 0.404 & 0.491 & 0.690 & 0.463 & 0.484 \\ 0.304 & 0.313 & 0.464 & 0.050 & 0.218 & 0.135 \\ 0.472 & 0.693 & 0.462 & 0.746 & 0.435 & 0.708 \\ 0.473 & 0.429 & 0.495 & 0.326 & 0.469 & 0.408 \\ 0.352 & 0.139 & 0.346 & 0.138 & 0.345 & 0.152 \\ 0.436 & 0.727 & 0.446 & 0.727 & 0.446 & 0.806 \\ 17.674 & 36.423 & 15.224 & 49.322 & 18.507 & 36.230 \\ 0.370 & 0.215 & 0.411 & 0.243 & 0.429 & 0.327 \\ 0.477 & 0.335 & 0.473 & 0.311 & 0.463 & 0.307\end{array}$

\begin{tabular}{|c|c|}
\hline mean & s.d. \\
\hline 0.516 & 0.500 \\
\hline 0.447 & 0.497 \\
\hline 0.244 & 0.430 \\
\hline 0.092 & 0.289 \\
\hline 0.196 & 0.397 \\
\hline 0.167 & 0.373 \\
\hline 0.309 & 0.462 \\
\hline 0.197 & 0.398 \\
\hline 0.634 & 0.482 \\
\hline 0.102 & 0.302 \\
\hline 0.736 & 0.441 \\
\hline 0.346 & 0.476 \\
\hline 0.138 & 0.345 \\
\hline 0.727 & 0.446 \\
\hline 46.784 & 18.626 \\
\hline 0.238 & 0.426 \\
\hline 0.316 & 0.465 \\
\hline 0.241 & 0.428 \\
\hline 0.416 & 0.493 \\
\hline 0.188 & 0.391 \\
\hline 0.347 & 0.476 \\
\hline 0.050 & 0.219 \\
\hline 0.415 & 0.493 \\
\hline 0.343 & 0.475 \\
\hline 0.445 & 0.497 \\
\hline 0.174 & 0.379 \\
\hline 0.038 & 0.191 \\
\hline
\end{tabular}

Without Children

1872

s.d. mean s.d.

$\begin{array}{lll}0.471 & 0.442 \quad 0.497\end{array}$

$\begin{array}{lll}0.496 & 0.391 & 0.488\end{array}$

$\begin{array}{lll}0.473 & 0.199 & 0.399\end{array}$

$\begin{array}{lll}0.413 & 0.031 & 0.172\end{array}$

$\begin{array}{lll}0.500 & 0.059 & 0.236\end{array}$

$\begin{array}{lll}0.492 & 0.049 & 0.216\end{array}$

$\begin{array}{lll}0.487 & 0.273 & 0.445\end{array}$

$\begin{array}{lll}0.457 & 0.148 & 0.356\end{array}$

$\begin{array}{lll}0.500 & 0.707 & 0.455\end{array}$

$\begin{array}{lll}0.342 & 0.085 & 0.280\end{array}$

$\begin{array}{lll}0.455 & 0.749 & 0.434\end{array}$

$\begin{array}{lll}0.492 & 0.316 & 0.465\end{array}$

$\begin{array}{lll}0.359 & 0.132 & 0.338\end{array}$

$\begin{array}{lll}0.396 & 0.689 & 0.463\end{array}$

$\begin{array}{lll}13.430 & 51.908 & 18.643\end{array}$

$\begin{array}{lll}0.469 & 0.194 & 0.396\end{array}$

$\begin{array}{lll}0.461 & 0.320 & 0.467\end{array}$ 
Table 2 (continued)

Full Sample $(N=2714)$

\begin{tabular}{|c|c|c|c|c|c|c|c|c|c|c|}
\hline \multicolumn{6}{|l|}{ Variables } & \multicolumn{2}{|l|}{ mean } & \multicolumn{3}{|l|}{ s.d. } \\
\hline Hispanic & 0.260 & 0.439 & 0.337 & 0.473 & 0.217 & 0.412 & 0.340 & 0.474 & 0.192 & 0.394 \\
\hline White & 0.360 & 0.480 & 0.290 & 0.454 & 0.447 & 0.497 & 0.317 & 0.465 & 0.465 & 0.499 \\
\hline College and Higher & 0.149 & 0.356 & 0.165 & 0.371 & 0.194 & 0.396 & 0.166 & 0.372 & 0.199 & 0.400 \\
\hline High School & 0.387 & 0.487 & 0.356 & 0.479 & 0.344 & 0.475 & 0.359 & 0.480 & 0.341 & 0.474 \\
\hline Less High School & 0.088 & 0.284 & 0.047 & 0.211 & 0.051 & 0.221 & 0.061 & 0.239 & 0.045 & 0.208 \\
\hline Some College & 0.376 & 0.485 & 0.433 & 0.496 & 0.410 & 0.492 & 0.415 & 0.493 & 0.414 & 0.493 \\
\hline Less $\$ 15,000$ & 0.791 & 0.407 & 0.375 & 0.484 & 0.335 & 0.472 & 0.275 & 0.447 & 0.376 & 0.485 \\
\hline$\$ 15,000-\$ 29,999$ & 0.172 & 0.378 & 0.397 & 0.490 & 0.456 & 0.498 & 0.374 & 0.484 & 0.479 & 0.500 \\
\hline$\$ 30,000-\$ 44,999$ & 0.036 & 0.186 & 0.189 & 0.392 & 0.171 & 0.376 & 0.256 & 0.437 & 0.135 & 0.341 \\
\hline \multirow[t]{2}{*}{$\$ 45,000$ and Above } & 0.001 & 0.029 & 0.039 & 0.195 & 0.038 & 0.190 & 0.095 & 0.293 & 0.010 & 0.101 \\
\hline & & Black & & & Hispanic & & & & White & \\
\hline \multirow[t]{2}{*}{ Sample Size } & & 857 & & & 653 & & & & 1130 & \\
\hline & & mean & & s.d. & mean & & s.d. & & mean & s.d. \\
\hline Food Insecurity (binary) & & 0.538 & & 0.499 & 0.574 & & 0.495 & & 0.462 & 0.499 \\
\hline SNAP & & 0.506 & & 0.500 & 0.415 & & 0.493 & & 0.428 & 0.495 \\
\hline Additional SNAP & & 0.289 & & 0.454 & 0.211 & & 0.409 & & 0.238 & 0.426 \\
\hline WIC & & 0.123 & & 0.328 & 0.109 & & 0.312 & & 0.055 & 0.228 \\
\hline School Meals & & 0.235 & & 0.424 & 0.250 & & 0.433 & & 0.135 & 0.341 \\
\hline Alternative School Meals & & 0.197 & & 0.398 & 0.228 & & 0.420 & & 0.102 & 0.302 \\
\hline Charitable Foods & & 0.372 & & 0.484 & 0.323 & & 0.468 & & 0.245 & 0.430 \\
\hline Lost Job & & 0.209 & & 0.407 & 0.276 & & 0.447 & & 0.137 & 0.344 \\
\hline Income Stable & & 0.586 & & 0.493 & 0.528 & & 0.500 & & 0.739 & 0.439 \\
\hline Unemployment Benefit & & 0.119 & & 0.324 & 0.144 & & 0.351 & & 0.065 & 0.246 \\
\hline Receive Stimulus & & 0.695 & & 0.460 & 0.658 & & 0.475 & & 0.812 & 0.391 \\
\hline Online Shopping & & 0.342 & & 0.475 & 0.377 & & 0.485 & & 0.329 & 0.470 \\
\hline Food Dessert & & 0.178 & & 0.382 & 0.090 & & 0.286 & & 0.139 & 0.346 \\
\hline Female & & 0.750 & & 0.433 & 0.727 & & 0.446 & & 0.715 & 0.452 \\
\hline Age & & 44.076 & & 18.492 & 37.894 & & 15.901 & & 54.367 & 17.292 \\
\hline Married & & 0.168 & & 0.374 & 0.257 & & 0.437 & & 0.273 & 0.446 \\
\hline College and Higher & & 0.181 & & 0.385 & 0.181 & & 0.385 & & 0.190 & 0.393 \\
\hline High School & & 0.345 & & 0.476 & 0.308 & & 0.462 & & 0.378 & 0.485 \\
\hline Less High School & & 0.054 & & 0.226 & 0.060 & & 0.237 & & 0.041 & 0.198 \\
\hline Some College & & 0.420 & & 0.494 & 0.452 & & 0.498 & & 0.391 & 0.488 \\
\hline Less $\$ 15,000$ & & 0.400 & & 0.490 & 0.326 & & 0.469 & & 0.312 & 0.463 \\
\hline$\$ 15,000-\$ 29,999$ & & 0.433 & & 0.496 & 0.383 & & 0.486 & & 0.491 & 0.500 \\
\hline$\$ 30,000-\$ 44,999$ & & 0.128 & & 0.335 & 0.245 & & 0.430 & & 0.165 & 0.371 \\
\hline$\$ 45,000$ and Above & & 0.039 & & 0.193 & 0.046 & & 0.210 & & 0.033 & 0.178 \\
\hline
\end{tabular}

a. Since income was reported as a category in our survey, we calculated the upper and lower bounds of SNAP eligible income based on household size. We then assigned respondents to be ineligible, definitely eligible, and possibly eligible depending on where they fell within the category. The SNAPeligible sample consists of only the respondents who were definitely eligible

sample. Based on income, children in these households would be eligible for free school meals which may explain the strong association.

In addition to Pandemic EBT, many school districts provided alternative meals for pickup or delivery during COVID- related school closures. In our sample, taking advantage of these alternative school meals is negatively associated with food insecurity across most subsamples but the magnitudes of the effect are small and insignificant. The one exception is the SNAP-eligible sample. Because this sample is 
Table 3 SEM Results

\begin{tabular}{|c|c|c|c|c|c|c|c|c|c|}
\hline & Full & SNAP Eligible $^{a}$ & Lost Job & Job & Children & No Children & Black & Hispanic & White \\
\hline Intercept & $\begin{array}{l}0.657 * * * \\
(0.077)\end{array}$ & $\begin{array}{l}0.682 * * * \\
(0.112)\end{array}$ & $\begin{array}{l}0.895 * * * \\
(0.150)\end{array}$ & $\begin{array}{l}0.616 * * * \\
(0.090)\end{array}$ & $\begin{array}{l}0.464 * * * \\
(0.127)\end{array}$ & $\begin{array}{l}0.779 * * * \\
(0.098)\end{array}$ & $\begin{array}{l}0.759 * * * \\
(0.104)\end{array}$ & $\begin{array}{l}0.502 * * * \\
(0.134)\end{array}$ & $\begin{array}{l}0.849 * * * \\
(0.094)\end{array}$ \\
\hline SNAP & $\begin{array}{l}0.241 * * * \\
(0.028)\end{array}$ & $\begin{array}{l}0.237 * * * \\
(0.040)\end{array}$ & $\begin{array}{l}0.021 \\
(0.051)\end{array}$ & $\begin{array}{l}0.302 * * * \\
(0.033)\end{array}$ & $\begin{array}{l}0.331 * * * \\
(0.046)\end{array}$ & $\begin{array}{l}0.217 * * * \\
(0.039)\end{array}$ & $\begin{array}{l}0.167 * * * \\
(0.046)\end{array}$ & $\begin{array}{l}0.360 * * * \\
(0.063)\end{array}$ & $\begin{array}{l}0.216^{* * * *} \\
(0.045)\end{array}$ \\
\hline Additional SNAP & $\begin{array}{l}-0.076^{* *} \\
(0.026)\end{array}$ & $\begin{array}{l}-0.036 \\
(0.036)\end{array}$ & $\begin{array}{l}-0.051 \\
(0.048)\end{array}$ & $\begin{array}{l}-0.089^{* *} \\
(0.030)\end{array}$ & $\begin{array}{l}-0.125^{* *} \\
(0.041)\end{array}$ & $\begin{array}{l}-0.059 \\
(0.034)\end{array}$ & $\begin{array}{l}-0.033 \\
(0.044)\end{array}$ & $\begin{array}{l}-0.104 \\
(0.057)\end{array}$ & $\begin{array}{l}-0.084 * \\
(0.040)\end{array}$ \\
\hline WIC & $\begin{array}{l}-0.014 \\
(0.032)\end{array}$ & $\begin{array}{l}-0.032 \\
(0.046)\end{array}$ & $\begin{array}{l}-0.001 \\
(0.050)\end{array}$ & $\begin{array}{l}0.026 \\
(0.041)\end{array}$ & $\begin{array}{l}0.000 \\
(0.037)\end{array}$ & $\begin{array}{l}0.113 \\
(0.069)\end{array}$ & $\begin{array}{l}-0.024 \\
(0.054)\end{array}$ & $\begin{array}{l}0.142 * \\
(0.062)\end{array}$ & $\begin{array}{l}-0.055 \\
(0.060)\end{array}$ \\
\hline School Meals & $\begin{array}{l}0.055 \\
(0.029)\end{array}$ & $\begin{array}{l}0.127 * * \\
(0.043)\end{array}$ & $\begin{array}{l}0.053 \\
(0.050)\end{array}$ & $\begin{array}{l}0.078 * \\
(0.036)\end{array}$ & $\begin{array}{l}0.062 \\
(0.034)\end{array}$ & $\begin{array}{l}-0.069 \\
(0.053)\end{array}$ & $\begin{array}{l}0.078 \\
(0.050)\end{array}$ & $\begin{array}{l}-0.065 \\
(0.053)\end{array}$ & $\begin{array}{l}0.149 * * \\
(0.056)\end{array}$ \\
\hline Alternative Meals & $\begin{array}{l}-0.040 \\
(0.030)\end{array}$ & $\begin{array}{l}-0.117 * * \\
(0.044)\end{array}$ & $\begin{array}{l}-0.007 \\
(0.050)\end{array}$ & $\begin{array}{l}-0.062 \\
(0.037)\end{array}$ & $\begin{array}{l}0.009 \\
(0.035)\end{array}$ & & $\begin{array}{l}-0.045 \\
(0.052)\end{array}$ & $\begin{array}{l}0.035 \\
(0.055)\end{array}$ & $\begin{array}{l}-0.082 \\
(0.058)\end{array}$ \\
\hline Charitable Food & $\begin{array}{l}0.290 * * * \\
(0.020)\end{array}$ & $\begin{array}{l}0.233 * * * \\
(0.029)\end{array}$ & $\begin{array}{l}0.248 * * * \\
(0.037)\end{array}$ & $\begin{array}{l}0.297 * * * \\
(0.023)\end{array}$ & $\begin{array}{l}0.191 * * * \\
(0.033)\end{array}$ & $\begin{array}{l}0.332 * * * \\
(0.025)\end{array}$ & $\begin{array}{l}0.251 * * * \\
(0.034)\end{array}$ & $\begin{array}{l}0.232 * * * \\
(0.042)\end{array}$ & $\begin{array}{l}0.386 * * * \\
(0.031)\end{array}$ \\
\hline Lost Job & $\begin{array}{l}0.143 * * * \\
(0.024)\end{array}$ & $\begin{array}{l}0.148 * * * \\
(0.035)\end{array}$ & & & $\begin{array}{l}0.174 * * * \\
(0.034)\end{array}$ & $\begin{array}{l}0.119 * * * \\
(0.033)\end{array}$ & $\begin{array}{l}0.183 * * * \\
(0.041)\end{array}$ & $\begin{array}{l}0.168 * * * \\
(0.045)\end{array}$ & $\begin{array}{l}0.043 \\
(0.042)\end{array}$ \\
\hline Income Stable & $\begin{array}{l}-0.129 * * * \\
(0.019)\end{array}$ & $\begin{array}{l}-0.095 * * \\
(0.030)\end{array}$ & $\begin{array}{l}-0.089 * \\
(0.035)\end{array}$ & $\begin{array}{l}-0.133 * * * \\
(0.023)\end{array}$ & $\begin{array}{l}-0.151 * * * \\
(0.031)\end{array}$ & $\begin{array}{l}-0.122 * * * \\
(0.025)\end{array}$ & $\begin{array}{l}-0.123 * * * \\
(0.034)\end{array}$ & $\begin{array}{l}-0.166^{* * * *} \\
(0.038)\end{array}$ & $\begin{array}{l}-0.097^{* *} \\
(0.033)\end{array}$ \\
\hline Rec. UI & $\begin{array}{l}-0.114 * * * \\
(0.030)\end{array}$ & $\begin{array}{l}-0.086 \\
(0.046)\end{array}$ & $\begin{array}{l}-0.155^{* * * *} \\
(0.038)\end{array}$ & $\begin{array}{l}-0.088 \\
(0.046)\end{array}$ & $\begin{array}{l}-0.165^{* * *} \\
(0.045)\end{array}$ & $\begin{array}{l}-0.076 \\
(0.041)\end{array}$ & $\begin{array}{l}-0.168 * * \\
(0.051)\end{array}$ & $\begin{array}{l}-0.055 \\
(0.056)\end{array}$ & $\begin{array}{l}-0.080 \\
(0.055)\end{array}$ \\
\hline Rec. Stimulus & $\begin{array}{l}-0.037 \\
(0.021)\end{array}$ & $\begin{array}{l}-0.107 * * * \\
(0.030)\end{array}$ & $\begin{array}{l}-0.034 \\
(0.039)\end{array}$ & $\begin{array}{l}-0.044 \\
(0.024)\end{array}$ & $\begin{array}{l}-0.029 \\
(0.034)\end{array}$ & $\begin{array}{l}-0.031 \\
(0.027)\end{array}$ & $\begin{array}{l}0.004 \\
(0.035)\end{array}$ & $\begin{array}{l}0.003 \\
(0.041)\end{array}$ & $\begin{array}{l}-0.122^{* * *} \\
(0.035)\end{array}$ \\
\hline Online Shopping & $\begin{array}{l}0.006 \\
(0.018)\end{array}$ & $\begin{array}{l}-0.000 \\
(0.029)\end{array}$ & $\begin{array}{l}0.029 \\
(0.036)\end{array}$ & $\begin{array}{l}0.004 \\
(0.021)\end{array}$ & $\begin{array}{l}0.002 \\
(0.031)\end{array}$ & $\begin{array}{l}0.001 \\
(0.023)\end{array}$ & $\begin{array}{l}-0.018 \\
(0.034)\end{array}$ & $\begin{array}{l}0.007 \\
(0.038)\end{array}$ & $\begin{array}{l}0.028 \\
(0.028)\end{array}$ \\
\hline Price Increase & $\begin{array}{l}0.137 * * * \\
(0.021)\end{array}$ & $\begin{array}{l}0.138 * * * \\
(0.031)\end{array}$ & $\begin{array}{l}0.122 * * \\
(0.043)\end{array}$ & $\begin{array}{l}0.140 * * * \\
(0.024)\end{array}$ & $\begin{array}{l}0.139 * * * \\
(0.035)\end{array}$ & $\begin{array}{l}0.138 * * * \\
(0.026)\end{array}$ & $\begin{array}{l}0.090 * \\
(0.038)\end{array}$ & $\begin{array}{l}0.131 * * \\
(0.044)\end{array}$ & $\begin{array}{l}0.184 * * * \\
(0.032)\end{array}$ \\
\hline Food Dessert & $\begin{array}{l}-0.015 \\
(0.025)\end{array}$ & $\begin{array}{l}-0.037 \\
(0.038)\end{array}$ & $\begin{array}{l}0.055 \\
(0.049)\end{array}$ & $\begin{array}{l}-0.031 \\
(0.028)\end{array}$ & $\begin{array}{l}0.005 \\
(0.041)\end{array}$ & $\begin{array}{l}-0.033 \\
(0.031)\end{array}$ & $\begin{array}{l}-0.054 \\
(0.040)\end{array}$ & $\begin{array}{l}0.003 \\
(0.064)\end{array}$ & $\begin{array}{l}0.033 \\
(0.037)\end{array}$ \\
\hline Female & $\begin{array}{l}0.001 \\
(0.019)\end{array}$ & $\begin{array}{l}0.015 \\
(0.031)\end{array}$ & $\begin{array}{l}-0.007 \\
(0.039)\end{array}$ & $\begin{array}{l}0.005 \\
(0.022)\end{array}$ & $\begin{array}{l}-0.023 \\
(0.038)\end{array}$ & $\begin{array}{l}0.004 \\
(0.023)\end{array}$ & $\begin{array}{l}-0.041 \\
(0.036)\end{array}$ & $\begin{array}{l}0.059 \\
(0.041)\end{array}$ & $\begin{array}{l}-0.002 \\
(0.029)\end{array}$ \\
\hline Age & $\begin{array}{l}-0.007 * * * \\
(0.001)\end{array}$ & $\begin{array}{l}-0.006^{* * *} \\
(0.001)\end{array}$ & $\begin{array}{l}-0.005 * * * \\
(0.001)\end{array}$ & $\begin{array}{l}-0.007 * * * \\
(0.001)\end{array}$ & $\begin{array}{l}-0.005 * * * \\
(0.001)\end{array}$ & $\begin{array}{l}-0.007 * * * \\
(0.001)\end{array}$ & $\begin{array}{l}-0.007 * * * \\
(0.001)\end{array}$ & $\begin{array}{l}-0.005 * * * \\
(0.001)\end{array}$ & $\begin{array}{l}-0.007 * * * \\
(0.001)\end{array}$ \\
\hline Married & $\begin{array}{l}-0.004 \\
(0.021)\end{array}$ & $\begin{array}{l}0.016 \\
(0.038)\end{array}$ & $\begin{array}{l}-0.098^{*} \\
(0.043)\end{array}$ & $\begin{array}{l}0.023 \\
(0.024)\end{array}$ & $\begin{array}{l}-0.026 \\
(0.033)\end{array}$ & $\begin{array}{l}0.016 \\
(0.028)\end{array}$ & $\begin{array}{l}-0.011 \\
(0.042)\end{array}$ & $\begin{array}{l}-0.036 \\
(0.044)\end{array}$ & $\begin{array}{l}0.026 \\
(0.031)\end{array}$ \\
\hline Black & $\begin{array}{l}0.016 \\
(0.053)\end{array}$ & $\begin{array}{l}0.003 \\
(0.081)\end{array}$ & $\begin{array}{l}0.004 \\
(0.095)\end{array}$ & $\begin{array}{l}0.028 \\
(0.064)\end{array}$ & $\begin{array}{l}0.038 \\
(0.082)\end{array}$ & $\begin{array}{l}-0.009 \\
(0.071)\end{array}$ & & & \\
\hline Hispanic & $\begin{array}{l}0.024 \\
(0.054)\end{array}$ & $\begin{array}{l}-0.006 \\
(0.082)\end{array}$ & $\begin{array}{l}0.025 \\
(0.093)\end{array}$ & $\begin{array}{l}0.029 \\
(0.065)\end{array}$ & $\begin{array}{l}0.046 \\
(0.081)\end{array}$ & $\begin{array}{l}-0.004 \\
(0.072)\end{array}$ & & & \\
\hline White & $\begin{array}{l}0.095 \\
(0.053)\end{array}$ & $\begin{array}{l}0.054 \\
(0.082)\end{array}$ & $\begin{array}{l}0.014 \\
(0.096)\end{array}$ & $\begin{array}{l}0.121 \\
(0.064)\end{array}$ & $\begin{array}{l}0.139 \\
(0.082)\end{array}$ & $\begin{array}{l}0.055 \\
(0.071)\end{array}$ & & & \\
\hline Child 3 More & $\begin{array}{l}0.178 * * \\
(0.063)\end{array}$ & $\begin{array}{l}0.116 \\
(0.085)\end{array}$ & $\begin{array}{l}-0.022 \\
(0.098)\end{array}$ & $\begin{array}{l}0.273 * * * \\
(0.079)\end{array}$ & $\begin{array}{l}0.123 \\
(0.063)\end{array}$ & & $\begin{array}{l}0.200 \\
(0.114)\end{array}$ & $\begin{array}{l}0.168 \\
(0.124)\end{array}$ & $\begin{array}{l}0.112 \\
(0.113)\end{array}$ \\
\hline High School & $\begin{array}{l}-0.055 \\
(0.041)\end{array}$ & $\begin{array}{l}-0.021 \\
(0.049)\end{array}$ & $\begin{array}{l}-0.022 \\
(0.084)\end{array}$ & $\begin{array}{l}-0.056 \\
(0.046)\end{array}$ & $\begin{array}{l}0.057 \\
(0.066)\end{array}$ & $\begin{array}{l}-0.113 * \\
(0.052)\end{array}$ & $\begin{array}{l}-0.041 \\
(0.070)\end{array}$ & $\begin{array}{l}0.054 \\
(0.082)\end{array}$ & $\begin{array}{l}-0.169^{*} \\
(0.067)\end{array}$ \\
\hline Some College & $\begin{array}{l}-0.006 \\
(0.040)\end{array}$ & $\begin{array}{l}0.002 \\
(0.050)\end{array}$ & $\begin{array}{l}-0.062 \\
(0.084)\end{array}$ & $\begin{array}{l}0.018 \\
(0.046)\end{array}$ & $\begin{array}{l}0.109 \\
(0.066)\end{array}$ & $\begin{array}{l}-0.066 \\
(0.052)\end{array}$ & $\begin{array}{l}0.012 \\
(0.070)\end{array}$ & $\begin{array}{l}0.035 \\
(0.080)\end{array}$ & $\begin{array}{l}-0.098 \\
(0.068)\end{array}$ \\
\hline College Higher & $\begin{array}{l}-0.020 \\
(0.043)\end{array}$ & $\begin{array}{l}-0.028 \\
(0.057)\end{array}$ & $\begin{array}{l}-0.039 \\
(0.090)\end{array}$ & $\begin{array}{l}-0.003 \\
(0.049)\end{array}$ & $\begin{array}{l}0.075 \\
(0.072)\end{array}$ & $\begin{array}{l}-0.068 \\
(0.055)\end{array}$ & $\begin{array}{l}0.018 \\
(0.076)\end{array}$ & $\begin{array}{l}0.022 \\
(0.088)\end{array}$ & $\begin{array}{l}-0.120 \\
(0.072)\end{array}$ \\
\hline Inc: $\$ 15,000-\$ 29,999$ & $-0.046^{*}$ & -0.008 & -0.047 & $-0.046^{*}$ & -0.000 & $-0.062 * *$ & $-0.092 * *$ & 0.005 & -0.012 \\
\hline
\end{tabular}


Table 3 (continued)

\begin{tabular}{lllllllllll}
\hline & Full & \multicolumn{2}{l}{ SNAP Eligible $^{\mathrm{a}}$} & Lost Job & Job & Children & No Children & Black & Hispanic & White \\
\hline \multirow{3}{*}{ Inc: $\$ 30,000-\$ 44,999$} & $(0.020)$ & $(0.040)$ & $(0.040)$ & $(0.023)$ & $(0.038)$ & $(0.024)$ & $(0.034)$ & $(0.044)$ & $(0.031)$ \\
& $-0.099^{* * *}$ & 0.001 & -0.018 & $-0.116^{* * *}$ & -0.056 & $-0.129^{* * *}$ & $-0.156^{* *}$ & -0.058 & $-0.087^{*}$ \\
Inc: $>\$ 45,000$ & $(0.027)$ & $(0.081)$ & $(0.050)$ & $(0.031)$ & $(0.043)$ & $(0.035)$ & $(0.051)$ & $(0.050)$ & $(0.044)$ \\
& $-0.095^{*}$ & -0.363 & -0.048 & $-0.112^{*}$ & -0.052 & -0.158 & -0.057 & -0.036 & $-0.197 *$ \\
$\mathrm{~N}$ & $(0.048)$ & $(0.457)$ & $(0.092)$ & $(0.056)$ & $(0.058)$ & $(0.104)$ & $(0.083)$ & $(0.093)$ & $(0.082)$ \\
& 2706 & & 1170 & 534 & 2172 & 883 & 1823 & 856 & 648 & 1128 \\
\hline
\end{tabular}

Notes: coefficients are marginal effects. Standard errors are in the parentheses. $* * *$, and $* * *$ indicate significance levels at $0.5,0.1$ and 0.01 , respectively

a. Since income was reported as a category in our survey, we calculated the upper and lower bounds of SNAP eligible income based on household size. We then assigned respondents to be ineligible, definitely eligible, and possibly eligible depending on where they fell within the category. The SNAPeligible sample consists of only the respondents who were definitely eligible

comprised of low-income households, this provides some evidence that alternative meal delivery programs were helping lower-income families during the pandemic. The fact that the association is significant only among the SNAP-eligible sample provides some evidence that alternative meal delivery programs were not sufficient to make up for the benefit of having meals in school among the lowest income households.

The associations between school meals are not significant among the subsample of households with children, but these households were more likely to receive Pandemic EBT supplements. This may have limited the impact of losing access to meals in the school environment and lessened their reliance on alternative school meal delivery and pickup programs. Moreover, data presented earlier in Table 2 indicate that nearly as many households with children that reported utilizing school meals before the pandemic took advantage of alternative meal delivery and pickup programs.

\subsection{Direct cash assistance}

The primary cash assistance programs in our data are the unemployment benefits and stimulus payments. Across the full sample and all subsamples, receipt of unemployment benefits is negatively associated with food insecurity with the strongest associations and significant associations are among those who lost a job due to the pandemic, households with children, and Black households. These strong associations suggest that unemployment benefits are helping to alleviate food insecurity and are consistent with recent findings by Bitler et al. (2020). The association in the Black sample is also consistent with Stone (2020) who finds the unemployment benefit was able to reduce the disparities in many southern states, with large Black populations, that have weak unemployment insurance (UI) systems. Receipt of economic stimulus payments is also negatively associated with food insecurity but this association is significant only among the SNAP-eligible sample and sample of White households. Economic assistance in the form of unemployment benefits had a much stronger negative association with food insecurity than did stimulus payments.

\subsection{Other covariates}

Other controls in the model can shed light on how food access and food procurement may relate to food insecurity. Residing in a food desert was not significantly associated with food insecurity in our data. $34.6 \%$ of our respondents were able to get groceries online. However, the estimates in Table 3 show that online shopping is not meaningfully associated with food insecurity. On the other hand, there is a small but positive association between driving distance to the store and food insecurity. This association is significant for the full sample and some of the subsamples and could indicate that access to stores during the pandemic impacted the ability of some respondents to obtain food. Notably, $77.8 \%$ of our respondents saw food price increases in their primary store, and this is strongly and positively associated with food insecurity.

These controls are also informative on the role of household structure. Among the sample who did not experience COVID-19 related job loss, having more than three children is significantly associated with food insecurity. It is possible that some of these households may have had to cut back work hours to take care of children who would otherwise have been in school. For those who did lose jobs, being married is negatively associated with food insecurity. Finally, age is negatively associated with food insecurity, likely due to the accumulation of savings. Support for this conjecture is provided by the strong negative association between the income stability indicator and food insecurity across all subsamples.

\section{Discussion}

Economic hardship brought on by the COVID-19 pandemic has increased food insecurity. This study explored how food 
and economic assistance programs are associated with food insecurity during very difficult times. Overall, our data show strong associations between assistance programs and food insecurity and point to several insights for food security and policy.

One implication is that there is a need to ensure that those newly at risk for food insecurity are able to connect to resources. Across our subsamples, those who lost jobs due to the pandemic had the highest level of food insecurity but the weakest associations with food assistance programs. Among this group, the only significant association was with the receipt of unemployment benefits, something most newly unemployed would know are available to them. The point is that food assistance programs may not be reaching those who have great need but little prior experience with food benefits. Hence, outreach to help these individuals better access food assistance is needed.

Another implication is that targeted assistance may be more effective than general assistance when it comes to food insecurity. For example, extending unemployment benefits may be a more effective strategy than additional broad-based cash transfers. Extending unemployment benefits would also be more cost effective by concentrating assistance to those in greatest need. Another example of effective targeting is with the Pandemic EBT Program to replace school meals. Behind the newly unemployed, households with children experienced the next highest level of food insecurity in our data and results presented above suggest that additional EBT transfers to these families helps reduce food insecurity.

The SNAP expansion is an example of a policy that seems to be not meeting the neediest Americans. This policy expanded benefits for those who were not already receiving the maximum benefit. In this respect, it did not impact those SNAP recipients who were in the worst economic condition prior to the policy change. We find little evidence that the SNAP expansion reduced food insecurity. The simplest explanation is that it had a limited impact on those at greatest economic disadvantage. In contrast, evidence of a negative association between food insecurity and SNAP expansion was observed among groups with higher levels of income stability including non-minority households and those not experiencing a job loss. Again, this is consistent with the SNAP expansion not impacting Americans most at risk for food insecurity. In fact, this conclusion is consistent with the Biden Administration's decision in December 2020 to increase SNAP benefits by $15 \%$ from January through June 2021 (Rosenbaum, 2021). On the other hand, food insecurity is still an issue among low-income but more financially stable households. For example, $45 \%$ of those not experiencing a job loss reported food insecurity during the first months of the pandemic. Workers in these households may have lost hours or income even if they continued to be employed or may struggle to purchase foods as school meals become less available.
Our data highlight the importance of school meal programs during normal times. Those in our survey that took advantage of school meals before the outbreak were more likely to have experienced food insecurity after the pandemic-related school closures. Short-term solutions such as alternative meal delivery or pickup programs, however, did not significantly decrease the likelihood of food insecurity except among the lowest-income respondents. Our results provide evidence that Pandemic EBT, designed to help offset the cost of meals that would otherwise have been provided in the schools, could be more effective at reducing food insecurity among households with children. The impact of emergency policy responses on health outcomes should also be investigated in future research. For example, shifting the responsibility of feeding children from school to parents may lead to negative health outcomes because school meals have been shown to improve the diets of children from homes with poor food environments (Smith, 2017).

Although recent studies have reported stockpiling behaviors among consumers during the early phases of the pandemic (Grose, 2020; Information Resources, Inc., 2020), the majority of our respondents had reported no trouble finding foods, even WIC food items. 77.8\% of our respondents, however, have reported price increase in their primary stores, and this has contributed to higher food insecurity. We did not find food access, i.e. food desert status or distance to the store, to be associated with food insecurity. Online food shopping was not associated with food insecurity. Online grocery industry was accelerated by the pandemic (Reardon et al., 2021). However, the delayed rollout of SNAP online pilots by the time of the survey and food access issue for SNAP participants (Fitzpatrick et al., 2016) may have contributed to this small percentage.

This study examined how the food assistance and economic assistance programs are associated with food insecurity in the US. While we cannot estimate the causal effects of these programs on food insecurity, we are able to show important associations that provide useful insights into how these programs could alleviate food insecurity during catastrophic periods such as during pandemics. In the absence of a large-scale nationwide database on food insecurity, our study provides timely and important insights into this issue during the pandemic. This is the first step in understanding how the food and economic assistance initiatives helped alleviate food insecurity during the pandemic. Future studies should examine whether any of these initiatives had a causal effect on the incidence of food insecurity in the US. A timely data source to study a similar topic during the pandemic is the Household Pulse Survey by the Census, which incorporated questions on food insufficiency and food hardship. 


\section{Appendix}

Table 4 Liner Probability Model Estimates

\begin{tabular}{|c|c|c|c|c|c|c|c|c|c|}
\hline & Full & SNAP & Lost Job & Employed & Children & No Children & Black & Hispanic & White \\
\hline SNAP & $\begin{array}{l}0.047 * * \\
(0.024)\end{array}$ & $\begin{array}{l}0.035 \\
(0.031)\end{array}$ & $\begin{array}{l}-0.047 \\
(0.042)\end{array}$ & $\begin{array}{l}0.080 * * * \\
(0.028)\end{array}$ & $\begin{array}{l}0.104 * * \\
(0.041)\end{array}$ & $\begin{array}{l}0.044 \\
(0.034)\end{array}$ & $\begin{array}{l}0.025 \\
(0.040)\end{array}$ & $\begin{array}{l}0.106^{* *} \\
(0.053)\end{array}$ & $\begin{array}{l}0.044 \\
(0.038)\end{array}$ \\
\hline Add. SNAP & $\begin{array}{l}0.003 \\
(0.027)\end{array}$ & $\begin{array}{l}0.007 \\
(0.036)\end{array}$ & $\begin{array}{l}-0.022 \\
(0.050)\end{array}$ & $\begin{array}{l}0.009 \\
(0.032)\end{array}$ & $\begin{array}{l}-0.021 \\
(0.042)\end{array}$ & $\begin{array}{l}-0.004 \\
(0.037)\end{array}$ & $\begin{array}{l}-0.010 \\
(0.045)\end{array}$ & $\begin{array}{l}0.040 \\
(0.063)\end{array}$ & $\begin{array}{l}-0.022 \\
(0.039)\end{array}$ \\
\hline WIC & $\begin{array}{l}-0.020 \\
(0.027)\end{array}$ & $\begin{array}{l}-0.005 \\
(0.038)\end{array}$ & $\begin{array}{l}-0.034 \\
(0.038)\end{array}$ & $\begin{array}{l}0.015 \\
(0.037)\end{array}$ & $\begin{array}{l}-0.012 \\
(0.031)\end{array}$ & $\begin{array}{l}-0.014 \\
(0.061)\end{array}$ & $\begin{array}{l}-0.015 \\
(0.048)\end{array}$ & $\begin{array}{l}0.022 \\
(0.049)\end{array}$ & $\begin{array}{l}-0.009 \\
(0.052)\end{array}$ \\
\hline School Meal & $\begin{array}{l}0.032 \\
(0.026)\end{array}$ & $\begin{array}{l}0.045 \\
(0.037)\end{array}$ & $\begin{array}{l}-0.011 \\
(0.044)\end{array}$ & $\begin{array}{l}0.069 * * \\
(0.032)\end{array}$ & $\begin{array}{l}0.041 \\
(0.031)\end{array}$ & $\begin{array}{l}0.005 \\
(0.046)\end{array}$ & $\begin{array}{l}0.019 \\
(0.045)\end{array}$ & $\begin{array}{l}-0.063 \\
(0.049)\end{array}$ & $\begin{array}{l}0.150 * * * \\
(0.045)\end{array}$ \\
\hline Alt.School Meal & $\begin{array}{l}-0.020 \\
(0.027)\end{array}$ & $\begin{array}{l}-0.029 \\
(0.038)\end{array}$ & $\begin{array}{l}0.026 \\
(0.042)\end{array}$ & $\begin{array}{l}-0.034 \\
(0.034)\end{array}$ & $\begin{array}{l}-0.022 \\
(0.031)\end{array}$ & & $\begin{array}{l}-0.009 \\
(0.047)\end{array}$ & $\begin{array}{l}0.019 \\
(0.051)\end{array}$ & $\begin{array}{l}-0.086^{* *} \\
(0.044)\end{array}$ \\
\hline Charitable Food & $\begin{array}{l}0.087 * * * \\
(0.017)\end{array}$ & $\begin{array}{l}0.069 * * * \\
(0.024)\end{array}$ & $\begin{array}{l}0.113 * * * \\
(0.033)\end{array}$ & $\begin{array}{l}0.076 * * * \\
(0.020)\end{array}$ & $\begin{array}{l}0.076^{* * *} \\
(0.029)\end{array}$ & $\begin{array}{l}0.081 * * * \\
(0.022)\end{array}$ & $\begin{array}{l}0.072 * * \\
(0.031)\end{array}$ & $\begin{array}{l}0.109 * * * \\
(0.038)\end{array}$ & $\begin{array}{l}0.083 * * * \\
(0.026)\end{array}$ \\
\hline Lost Job & $\begin{array}{l}0.102 * * * \\
(0.020)\end{array}$ & $\begin{array}{l}0.128 * * * \\
(0.028)\end{array}$ & & & $\begin{array}{l}0.118 * * * \\
(0.027)\end{array}$ & $\begin{array}{l}0.096^{* * * *} \\
(0.029)\end{array}$ & $\begin{array}{l}0.117 * * * \\
(0.035)\end{array}$ & $\begin{array}{l}0.162 * * * \\
(0.038)\end{array}$ & $\begin{array}{l}0.007 \\
(0.033)\end{array}$ \\
\hline Income Stable & $\begin{array}{l}-0.096^{* * *} \\
(0.018)\end{array}$ & $\begin{array}{l}-0.059 * * \\
(0.025)\end{array}$ & $\begin{array}{l}-0.069 * * \\
(0.033)\end{array}$ & $\begin{array}{l}-0.103 * * * \\
(0.021)\end{array}$ & $\begin{array}{l}-0.118 * * * \\
(0.028)\end{array}$ & $\begin{array}{l}-0.081 * * * \\
(0.023)\end{array}$ & $\begin{array}{l}-0.086^{* * *} \\
(0.031)\end{array}$ & $\begin{array}{l}-0.122^{* * *} \\
(0.034)\end{array}$ & $\begin{array}{l}-0.084 * * * \\
(0.030)\end{array}$ \\
\hline Rec. UI & $\begin{array}{l}-0.055^{* *} \\
(0.028)\end{array}$ & $\begin{array}{l}-0.026 \\
(0.041)\end{array}$ & $\begin{array}{l}-0.090^{* *} \\
(0.038)\end{array}$ & $\begin{array}{l}-0.049 \\
(0.043)\end{array}$ & $\begin{array}{l}-0.123 * * * \\
(0.040)\end{array}$ & $\begin{array}{l}-0.006 \\
(0.039)\end{array}$ & $\begin{array}{l}-0.124 * * * \\
(0.046)\end{array}$ & $\begin{array}{l}-0.009 \\
(0.051)\end{array}$ & $\begin{array}{l}-0.019 \\
(0.050)\end{array}$ \\
\hline Rec. Stimulus & $\begin{array}{l}-0.013 \\
(0.027)\end{array}$ & $\begin{array}{l}-0.050 \\
(0.038)\end{array}$ & $\begin{array}{l}-0.034 \\
(0.048)\end{array}$ & $\begin{array}{l}-0.004 \\
(0.033)\end{array}$ & $\begin{array}{l}0.036 \\
(0.042)\end{array}$ & $\begin{array}{l}-0.052 \\
(0.040)\end{array}$ & $\begin{array}{l}-0.009 \\
(0.050)\end{array}$ & $\begin{array}{l}0.020 \\
(0.053)\end{array}$ & $\begin{array}{l}-0.072 \\
(0.046)\end{array}$ \\
\hline Online Shopping & $\begin{array}{l}-0.015 \\
(0.015)\end{array}$ & $\begin{array}{l}-0.035 \\
(0.024)\end{array}$ & $\begin{array}{l}-0.013 \\
(0.031)\end{array}$ & $\begin{array}{l}-0.008 \\
(0.018)\end{array}$ & $\begin{array}{l}-0.011 \\
(0.027)\end{array}$ & $\begin{array}{l}-0.023 \\
(0.019)\end{array}$ & $\begin{array}{l}-0.052 * \\
(0.029)\end{array}$ & $\begin{array}{l}0.0003 \\
(0.034)\end{array}$ & $\begin{array}{l}0.003 \\
(0.022)\end{array}$ \\
\hline Price Increase & $\begin{array}{l}0.074 * * * \\
(0.018)\end{array}$ & $\begin{array}{l}0.053 * * \\
(0.027)\end{array}$ & $\begin{array}{l}0.067 * \\
(0.038)\end{array}$ & $\begin{array}{l}0.073 * * * \\
(0.020)\end{array}$ & $\begin{array}{l}0.076^{* *} \\
(0.032)\end{array}$ & $\begin{array}{l}0.079 * * * \\
(0.022)\end{array}$ & $\begin{array}{l}0.060 * \\
(0.034)\end{array}$ & $\begin{array}{l}0.083 * * \\
(0.039)\end{array}$ & $\begin{array}{l}0.081 * * * \\
(0.026)\end{array}$ \\
\hline Food Dessert & $\begin{array}{l}-0.005 \\
(0.021)\end{array}$ & $\begin{array}{l}0.0001 \\
(0.031)\end{array}$ & $\begin{array}{l}0.090 * \\
(0.047)\end{array}$ & $\begin{array}{l}-0.031 \\
(0.023)\end{array}$ & $\begin{array}{l}-0.002 \\
(0.034)\end{array}$ & $\begin{array}{l}-0.007 \\
(0.027)\end{array}$ & $\begin{array}{l}-0.049 \\
(0.034)\end{array}$ & $\begin{array}{l}0.027 \\
(0.056)\end{array}$ & $\begin{array}{l}0.027 \\
(0.032)\end{array}$ \\
\hline Min. to Store & $\begin{array}{l}0.001 \\
(0.001)\end{array}$ & $\begin{array}{l}-0.001 \\
(0.001)\end{array}$ & $\begin{array}{l}0.001 \\
(0.001)\end{array}$ & $\begin{array}{l}0.0004 \\
(0.001)\end{array}$ & $\begin{array}{l}0.0004 \\
(0.001)\end{array}$ & $\begin{array}{l}0.001 \\
(0.001)\end{array}$ & $\begin{array}{l}0.002 * \\
(0.001)\end{array}$ & $\begin{array}{l}-0.00001 \\
(0.002)\end{array}$ & $\begin{array}{l}-0.002 \\
(0.001)\end{array}$ \\
\hline Female & $\begin{array}{l}-0.032 * * \\
(0.016)\end{array}$ & $\begin{array}{l}-0.031 \\
(0.025)\end{array}$ & $\begin{array}{l}-0.022 \\
(0.037)\end{array}$ & $\begin{array}{l}-0.037 * * \\
(0.018)\end{array}$ & $\begin{array}{l}-0.054^{*} \\
(0.032)\end{array}$ & $\begin{array}{l}-0.028 \\
(0.019)\end{array}$ & $\begin{array}{l}-0.061 * * \\
(0.030)\end{array}$ & $\begin{array}{l}-0.020 \\
(0.037)\end{array}$ & $\begin{array}{l}-0.006 \\
(0.023)\end{array}$ \\
\hline Age & $\begin{array}{l}-0.004 * * * \\
(0.001)\end{array}$ & $\begin{array}{l}-0.002 * * \\
(0.001)\end{array}$ & $\begin{array}{l}-0.005 * * * \\
(0.001)\end{array}$ & $\begin{array}{l}-0.003 * * * \\
(0.001)\end{array}$ & $\begin{array}{l}-0.003 * * \\
(0.001)\end{array}$ & $\begin{array}{l}-0.004 * * * \\
(0.001)\end{array}$ & $\begin{array}{l}-0.005 * * * \\
(0.001)\end{array}$ & $\begin{array}{l}-0.003^{* *} \\
(0.001)\end{array}$ & $\begin{array}{l}-0.003 * * * \\
(0.001)\end{array}$ \\
\hline Married & $\begin{array}{l}-0.015 \\
(0.019)\end{array}$ & $\begin{array}{l}-0.009 \\
(0.032)\end{array}$ & $\begin{array}{l}-0.078 * \\
(0.042)\end{array}$ & $\begin{array}{l}0.005 \\
(0.021)\end{array}$ & $\begin{array}{l}-0.014 \\
(0.031)\end{array}$ & $\begin{array}{l}-0.014 \\
(0.024)\end{array}$ & $\begin{array}{l}-0.017 \\
(0.039)\end{array}$ & $\begin{array}{l}-0.023 \\
(0.041)\end{array}$ & $\begin{array}{l}-0.008 \\
(0.026)\end{array}$ \\
\hline Black & $\begin{array}{l}0.030 \\
(0.042)\end{array}$ & $\begin{array}{l}0.015 \\
(0.061)\end{array}$ & $\begin{array}{l}0.023 \\
(0.084)\end{array}$ & $\begin{array}{l}0.035 \\
(0.049)\end{array}$ & $\begin{array}{l}0.008 \\
(0.070)\end{array}$ & $\begin{array}{l}0.055 \\
(0.054)\end{array}$ & & & \\
\hline Hispanic & $\begin{array}{l}0.015 \\
(0.043)\end{array}$ & $\begin{array}{l}-0.021 \\
(0.062)\end{array}$ & $\begin{array}{l}0.047 \\
(0.083)\end{array}$ & $\begin{array}{l}-0.004 \\
(0.050)\end{array}$ & $\begin{array}{l}-0.012 \\
(0.068)\end{array}$ & $\begin{array}{l}0.038 \\
(0.056)\end{array}$ & & & \\
\hline White & $\begin{array}{l}0.065 \\
(0.041)\end{array}$ & $\begin{array}{l}0.033 \\
(0.061)\end{array}$ & $\begin{array}{l}0.004 \\
(0.084)\end{array}$ & $\begin{array}{l}0.074 \\
(0.048)\end{array}$ & $\begin{array}{l}0.029 \\
(0.068)\end{array}$ & $\begin{array}{l}0.094 * \\
(0.053)\end{array}$ & & & \\
\hline Child3 More & $\begin{array}{l}0.117 * * \\
(0.054)\end{array}$ & $\begin{array}{l}0.048 \\
(0.069)\end{array}$ & $\begin{array}{l}0.017 \\
(0.091)\end{array}$ & $\begin{array}{l}0.158 * * \\
(0.070)\end{array}$ & $\begin{array}{l}0.090 * \\
(0.054)\end{array}$ & & $\begin{array}{l}0.123 \\
(0.106)\end{array}$ & $\begin{array}{l}0.115 \\
(0.075)\end{array}$ & $\begin{array}{l}0.035 \\
(0.117)\end{array}$ \\
\hline High School & $\begin{array}{l}-0.001 \\
(0.034)\end{array}$ & $\begin{array}{l}0.019 \\
(0.040)\end{array}$ & $\begin{array}{l}-0.008 \\
(0.066)\end{array}$ & $\begin{array}{l}0.011 \\
(0.039)\end{array}$ & $\begin{array}{l}0.058 \\
(0.054)\end{array}$ & $\begin{array}{l}-0.030 \\
(0.043)\end{array}$ & $\begin{array}{l}0.013 \\
(0.062)\end{array}$ & $\begin{array}{l}0.035 \\
(0.067)\end{array}$ & $\begin{array}{l}-0.059 \\
(0.051)\end{array}$ \\
\hline Some College & $\begin{array}{l}0.041 \\
(0.034)\end{array}$ & $\begin{array}{l}0.059 \\
(0.041)\end{array}$ & $\begin{array}{l}-0.004 \\
(0.068)\end{array}$ & $\begin{array}{l}0.057 \\
(0.039)\end{array}$ & $\begin{array}{l}0.109 * * \\
(0.056)\end{array}$ & $\begin{array}{l}0.009 \\
(0.043)\end{array}$ & $\begin{array}{l}0.079 \\
(0.063)\end{array}$ & $\begin{array}{l}0.045 \\
(0.066)\end{array}$ & $\begin{array}{l}-0.023 \\
(0.051)\end{array}$ \\
\hline
\end{tabular}


Table 4 (continued)

\begin{tabular}{llllllllll}
\hline & Full & SNAP & Lost Job & Employed & Children & No Children & Black & Hispanic & White \\
\hline College Higher & 0.039 & 0.052 & 0.013 & 0.061 & 0.064 & 0.030 & 0.107 & 0.029 & -0.034 \\
& $(0.037)$ & $(0.047)$ & $(0.074)$ & $(0.042)$ & $(0.062)$ & $(0.046)$ & $(0.069)$ & $(0.075)$ & $(0.055)$ \\
$15,000-29,999$ & -0.021 & 0.031 & -0.022 & -0.021 & 0.015 & $-0.033 *$ & $-0.050^{*}$ & 0.025 & -0.013 \\
& $(0.017)$ & $(0.035)$ & $(0.036)$ & $(0.019)$ & $(0.032)$ & $(0.020)$ & $(0.030)$ & $(0.039)$ & $(0.025)$ \\
$30,000-44,999$ & $-0.046^{*}$ & $0.115^{*}$ & -0.014 & $-0.046^{*}$ & -0.011 & $-0.066^{* *}$ & $-0.100^{* *}$ & 0.012 & -0.049 \\
& $(0.024)$ & $(0.066)$ & $(0.045)$ & $(0.028)$ & $(0.038)$ & $(0.030)$ & $(0.045)$ & $(0.044)$ & $(0.038)$ \\
$>45,000$ & -0.048 & -0.137 & -0.031 & -0.055 & -0.002 & -0.139 & -0.029 & -0.007 & -0.062 \\
& $(0.041)$ & $(0.083)$ & $(0.084)$ & $(0.047)$ & $(0.049)$ & $(0.097)$ & $(0.080)$ & $(0.073)$ & $(0.064)$ \\
Intercept & $0.404 * * *$ & $0.386^{* * *}$ & $0.610^{* * *}$ & $0.366^{* * *}$ & $0.340^{* * *}$ & $0.425^{* * *}$ & $0.563 * * *$ & $0.250^{* *}$ & $0.506 * * *$ \\
& $(0.066)$ & $(0.095)$ & $(0.137)$ & $(0.075)$ & $(0.112)$ & $(0.083)$ & $(0.098)$ & $(0.112)$ & $(0.083)$ \\
$\mathrm{N}$ & 2706 & 1170 & 534 & 2172 & 883 & 1823 & 856 & 648 & 1128 \\
\hline
\end{tabular}

Notes: coefficients are marginal effects. Standard errors are in the parentheses. ***, and *** indicate significance levels at $0.5,0.1$ and 0.01 , respectively

Table 5 Logit Model Results

\begin{tabular}{|c|c|c|c|c|c|c|c|c|c|}
\hline & Full & SNAP & Lost Job & Job & Children & No Children & Black & Hispanic & White \\
\hline SNAP & $\begin{array}{l}0.419 * * \\
(0.182)\end{array}$ & $\begin{array}{l}0.348 \\
(0.263)\end{array}$ & $\begin{array}{l}-0.462 \\
(0.484)\end{array}$ & $\begin{array}{l}0.635 * * * \\
(0.203)\end{array}$ & $\begin{array}{l}0.881 * * * \\
(0.329)\end{array}$ & $\begin{array}{l}0.382 \\
(0.245)\end{array}$ & $\begin{array}{l}0.339 \\
(0.309)\end{array}$ & $\begin{array}{l}0.866 * * \\
(0.393)\end{array}$ & $\begin{array}{l}0.364 \\
(0.338)\end{array}$ \\
\hline Add. SNAP & $\begin{array}{l}0.032 \\
(0.203)\end{array}$ & $\begin{array}{l}0.148 \\
(0.285)\end{array}$ & $\begin{array}{l}-0.608 \\
(0.568)\end{array}$ & $\begin{array}{l}0.017 \\
(0.223)\end{array}$ & $\begin{array}{l}-0.117 \\
(0.362)\end{array}$ & $\begin{array}{l}-0.029 \\
(0.261)\end{array}$ & $\begin{array}{l}-0.231 \\
(0.351)\end{array}$ & $\begin{array}{l}0.421 \\
(0.427)\end{array}$ & $\begin{array}{l}-0.199 \\
(0.363)\end{array}$ \\
\hline WIC & $\begin{array}{l}0.043 \\
(0.228)\end{array}$ & $\begin{array}{l}0.213 \\
(0.340)\end{array}$ & $\begin{array}{l}-0.279 \\
(0.523)\end{array}$ & $\begin{array}{l}0.161 \\
(0.260)\end{array}$ & $\begin{array}{l}0.067 \\
(0.268)\end{array}$ & $\begin{array}{l}0.150 \\
(0.526)\end{array}$ & $\begin{array}{l}0.231 \\
(0.389)\end{array}$ & $\begin{array}{l}0.384 \\
(0.423)\end{array}$ & $\begin{array}{l}-0.078 \\
(0.478)\end{array}$ \\
\hline School Meal & $\begin{array}{l}0.376^{* *} \\
(0.190)\end{array}$ & $\begin{array}{l}0.641 * * \\
(0.299)\end{array}$ & $\begin{array}{l}-0.171 \\
(0.469)\end{array}$ & $\begin{array}{l}0.536 * * \\
(0.215)\end{array}$ & $\begin{array}{l}0.453 * \\
(0.231)\end{array}$ & $\begin{array}{l}0.095 \\
(0.355)\end{array}$ & $\begin{array}{l}0.247 \\
(0.325)\end{array}$ & $\begin{array}{l}-0.257 \\
(0.328)\end{array}$ & $\begin{array}{l}1.558 * * * \\
(0.419)\end{array}$ \\
\hline Alt.School Meal & $\begin{array}{l}-0.103 \\
(0.195)\end{array}$ & $\begin{array}{l}-0.173 \\
(0.289)\end{array}$ & $\begin{array}{l}0.456 \\
(0.487)\end{array}$ & $\begin{array}{l}-0.213 \\
(0.221)\end{array}$ & $\begin{array}{l}-0.173 \\
(0.235)\end{array}$ & & $\begin{array}{l}0.047 \\
(0.332)\end{array}$ & $\begin{array}{l}0.034 \\
(0.327)\end{array}$ & $\begin{array}{l}-0.692 \\
(0.457)\end{array}$ \\
\hline Charitable Food & $\begin{array}{l}0.620 * * * \\
(0.126)\end{array}$ & $\begin{array}{l}0.553 * * * \\
(0.189)\end{array}$ & $\begin{array}{l}1.210 * * * \\
(0.343)\end{array}$ & $\begin{array}{l}0.528 \text { **** } \\
(0.140)\end{array}$ & $\begin{array}{l}0.673 * * * \\
(0.230)\end{array}$ & $\begin{array}{l}0.577 * * * \\
(0.155)\end{array}$ & $\begin{array}{l}0.529 * * \\
(0.214)\end{array}$ & $\begin{array}{l}0.800 * * * \\
(0.247)\end{array}$ & $\begin{array}{l}0.733 * * * \\
(0.234)\end{array}$ \\
\hline Lost Job & $\begin{array}{l}0.883 * * * \\
(0.163)\end{array}$ & $\begin{array}{l}1.228 * * * \\
(0.257)\end{array}$ & & & $\begin{array}{l}1.244 * * * \\
(0.277)\end{array}$ & $\begin{array}{l}0.686^{* * * *} \\
(0.210)\end{array}$ & $\begin{array}{l}1.111 * * * \\
(0.296)\end{array}$ & $\begin{array}{l}1.176 * * * \\
(0.285)\end{array}$ & $\begin{array}{l}0.084 \\
(0.313)\end{array}$ \\
\hline Income Stable & $\begin{array}{l}-0.698 * * * \\
(0.121)\end{array}$ & $\begin{array}{l}-0.525^{* * * *} \\
(0.190)\end{array}$ & $\begin{array}{l}-0.722 * * \\
(0.296)\end{array}$ & $\begin{array}{l}-0.724 * * * \\
(0.138)\end{array}$ & $\begin{array}{l}-0.885^{* * * *} \\
(0.205)\end{array}$ & $\begin{array}{l}-0.563 \text { *** } \\
(0.155)\end{array}$ & $\begin{array}{l}-0.650 * * * \\
(0.215)\end{array}$ & $\begin{array}{l}-0.812 * * * \\
(0.221)\end{array}$ & $\begin{array}{l}-0.745 * * * \\
(0.230)\end{array}$ \\
\hline Rec. UI & $\begin{array}{l}-0.447^{* *} \\
(0.200)\end{array}$ & $\begin{array}{l}-0.199 \\
(0.311)\end{array}$ & $\begin{array}{l}-0.888^{* * * *} \\
(0.326)\end{array}$ & $\begin{array}{l}-0.205 \\
(0.285)\end{array}$ & $\begin{array}{l}-1.163 * * * \\
(0.328)\end{array}$ & $\begin{array}{l}0.009 \\
(0.255)\end{array}$ & $\begin{array}{l}-1.011^{* * * *} \\
(0.346)\end{array}$ & $\begin{array}{l}-0.054 \\
(0.343)\end{array}$ & $\begin{array}{l}-0.016 \\
(0.407)\end{array}$ \\
\hline Rec. Stimulus & $\begin{array}{l}-0.025 \\
(0.211)\end{array}$ & $\begin{array}{l}-0.280 \\
(0.321)\end{array}$ & $\begin{array}{l}0.079 \\
(0.539)\end{array}$ & $\begin{array}{l}-0.051 \\
(0.238)\end{array}$ & $\begin{array}{l}0.298 \\
(0.346)\end{array}$ & $\begin{array}{l}-0.339 \\
(0.307)\end{array}$ & $\begin{array}{l}0.081 \\
(0.408)\end{array}$ & $\begin{array}{l}0.273 \\
(0.382)\end{array}$ & $\begin{array}{l}-0.687^{*} \\
(0.393)\end{array}$ \\
\hline Stimulus Amount & $\begin{array}{l}-0.088 \\
(0.122)\end{array}$ & $\begin{array}{l}-0.153 \\
(0.192)\end{array}$ & $\begin{array}{l}0.079 \\
(0.316)\end{array}$ & $\begin{array}{l}-0.107 \\
(0.138)\end{array}$ & $\begin{array}{l}-0.267^{*} \\
(0.162)\end{array}$ & $\begin{array}{l}0.175 \\
(0.211)\end{array}$ & $\begin{array}{l}-0.050 \\
(0.272)\end{array}$ & $\begin{array}{l}-0.116 \\
(0.215)\end{array}$ & $\begin{array}{l}-0.003 \\
(0.216)\end{array}$ \\
\hline Online Shopping & $\begin{array}{c}-0.082 \\
(0.117)\end{array}$ & $\begin{array}{l}-0.200 \\
(0.188)\end{array}$ & $\begin{array}{l}-0.338 \\
(0.327)\end{array}$ & $\begin{array}{l}-0.055 \\
(0.128)\end{array}$ & $\begin{array}{r}-0.050 \\
(0.208)\end{array}$ & $\begin{array}{r}-0.144 \\
(0.145)\end{array}$ & $\begin{array}{l}-0.391 * \\
(0.218)\end{array}$ & $\begin{array}{l}0.025 \\
(0.229)\end{array}$ & $\begin{array}{l}0.033 \\
(0.199)\end{array}$ \\
\hline Price Increase & $\begin{array}{l}0.511 \text { **** } \\
(0.132)\end{array}$ & $\begin{array}{l}0.369 * \\
(0.196)\end{array}$ & $\begin{array}{l}0.476 \\
(0.353)\end{array}$ & $\begin{array}{l}0.510 * * * \\
(0.147)\end{array}$ & $\begin{array}{l}0.502 * * \\
(0.232)\end{array}$ & $\begin{array}{l}0.550 * * * \\
(0.165)\end{array}$ & $\begin{array}{l}0.485^{* *} \\
(0.244)\end{array}$ & $\begin{array}{l}0.461 * \\
(0.253)\end{array}$ & $\begin{array}{l}0.735 * * * \\
(0.237)\end{array}$ \\
\hline Food Dessert & $\begin{array}{l}-0.104 \\
(0.158)\end{array}$ & $\begin{array}{l}-0.122 \\
(0.243)\end{array}$ & $\begin{array}{l}0.838^{*} \\
(0.442)\end{array}$ & $\begin{array}{l}-0.227 \\
(0.176)\end{array}$ & $\begin{array}{l}-0.131 \\
(0.284)\end{array}$ & $\begin{array}{r}-0.118 \\
(0.196)\end{array}$ & $\begin{array}{l}-0.452^{*} \\
(0.253)\end{array}$ & $\begin{array}{l}0.139 \\
(0.376)\end{array}$ & $\begin{array}{l}0.112 \\
(0.265)\end{array}$ \\
\hline Min. to Store & $\begin{array}{l}0.004 \\
(0.006)\end{array}$ & $\begin{array}{l}-0.016 \\
(0.010)\end{array}$ & $\begin{array}{l}0.023 \\
(0.017)\end{array}$ & $\begin{array}{l}0.003 \\
(0.007)\end{array}$ & $\begin{array}{l}0.004 \\
(0.012)\end{array}$ & $\begin{array}{l}0.006 \\
(0.008)\end{array}$ & $\begin{array}{l}0.021 * * \\
(0.010)\end{array}$ & $\begin{array}{l}-0.0002 \\
(0.014)\end{array}$ & $\begin{array}{l}-0.019 * \\
(0.011)\end{array}$ \\
\hline Female & $\begin{array}{l}-0.246^{* * *} \\
(0.121)\end{array}$ & $\begin{array}{l}-0.256 \\
(0.198)\end{array}$ & $\begin{array}{l}-0.100 \\
(0.328)\end{array}$ & $\begin{array}{l}-0.279 * * \\
(0.134)\end{array}$ & $\begin{array}{l}-0.442 * \\
(0.260)\end{array}$ & $\begin{array}{l}-0.208 \\
(0.140)\end{array}$ & $\begin{array}{l}-0.487 * * \\
(0.232)\end{array}$ & $\begin{array}{l}-0.058 \\
(0.239)\end{array}$ & $\begin{array}{l}-0.081 \\
(0.200)\end{array}$ \\
\hline Age & $\begin{array}{l}-0.024 * * * \\
(0.004)\end{array}$ & $\begin{array}{l}-0.011 * \\
(0.006)\end{array}$ & $\begin{array}{l}-0.039 * * * \\
(0.011)\end{array}$ & $\begin{array}{l}-0.023 * * * \\
(0.004)\end{array}$ & $\begin{array}{l}-0.019 * * \\
(0.008)\end{array}$ & $\begin{array}{l}-0.029 * * * \\
(0.005)\end{array}$ & $\begin{array}{l}-0.034 * * * \\
(0.007)\end{array}$ & $\begin{array}{l}-0.017 * * \\
(0.008)\end{array}$ & $\begin{array}{l}-0.024 * * * \\
(0.007)\end{array}$ \\
\hline Married & $\begin{array}{l}-0.109 \\
(0.141)\end{array}$ & $\begin{array}{l}-0.112 \\
(0.257)\end{array}$ & $\begin{array}{l}-0.836^{* * *} \\
(0.376)\end{array}$ & $\begin{array}{l}0.034 \\
(0.156)\end{array}$ & $\begin{array}{r}-0.135 \\
(0.236)\end{array}$ & $\begin{array}{l}-0.106 \\
(0.185)\end{array}$ & $\begin{array}{l}-0.150 \\
(0.272)\end{array}$ & $\begin{array}{l}-0.088 \\
(0.277)\end{array}$ & $\begin{array}{l}-0.047 \\
(0.236)\end{array}$ \\
\hline Black & $\begin{array}{l}0.315 \\
(0.344)\end{array}$ & $\begin{array}{l}0.245 \\
(0.502)\end{array}$ & $\begin{array}{l}0.285 \\
(0.879)\end{array}$ & $\begin{array}{l}0.347 \\
(0.386)\end{array}$ & $\begin{array}{l}0.169 \\
(0.526)\end{array}$ & $\begin{array}{l}0.475 \\
(0.479)\end{array}$ & & & \\
\hline Hispanic & 0.182 & -0.081 & 0.571 & 0.089 & -0.014 & 0.337 & & & \\
\hline
\end{tabular}


Table 5 (continued)

\begin{tabular}{|c|c|c|c|c|c|c|c|c|c|}
\hline & Full & SNAP & Lost Job & Job & Children & No Children & Black & Hispanic & White \\
\hline & $(0.347)$ & $(0.506)$ & $(0.854)$ & $(0.391)$ & $(0.521)$ & $(0.485)$ & & & \\
\hline White & $\begin{array}{l}0.580^{*} \\
(0.345)\end{array}$ & $\begin{array}{l}0.396 \\
(0.506)\end{array}$ & $\begin{array}{l}0.303 \\
(0.901)\end{array}$ & $\begin{array}{l}0.645^{*} \\
(0.386)\end{array}$ & $\begin{array}{l}0.349 \\
(0.536)\end{array}$ & $\begin{array}{l}0.757 \\
(0.477)\end{array}$ & & & \\
\hline Child 3 More & $\begin{array}{l}0.910^{* *} \\
(0.424)\end{array}$ & $\begin{array}{l}0.442 \\
(0.589)\end{array}$ & $\begin{array}{l}-0.085 \\
(0.828)\end{array}$ & $\begin{array}{l}1.175^{* *} \\
(0.500)\end{array}$ & $\begin{array}{l}0.712 \\
(0.446)\end{array}$ & & $\begin{array}{l}0.638 \\
(0.716)\end{array}$ & $\begin{array}{l}0.844 \\
(0.841)\end{array}$ & $\begin{array}{l}0.372 \\
(0.848)\end{array}$ \\
\hline High School & $\begin{array}{l}0.115 \\
(0.261)\end{array}$ & $\begin{array}{l}0.291 \\
(0.321)\end{array}$ & $\begin{array}{l}0.361 \\
(0.793)\end{array}$ & $\begin{array}{l}0.147 \\
(0.284)\end{array}$ & $\begin{array}{l}0.592 \\
(0.444)\end{array}$ & $\begin{array}{l}-0.100 \\
(0.334)\end{array}$ & $\begin{array}{l}0.127 \\
(0.433)\end{array}$ & $\begin{array}{l}0.311 \\
(0.504)\end{array}$ & $\begin{array}{l}-0.386 \\
(0.519)\end{array}$ \\
\hline Some College & $\begin{array}{l}0.410 \\
(0.260)\end{array}$ & $\begin{array}{l}0.595 * \\
(0.323)\end{array}$ & $\begin{array}{l}0.595 \\
(0.801)\end{array}$ & $\begin{array}{l}0.493 * \\
(0.282)\end{array}$ & $\begin{array}{l}1.015^{* *} \\
(0.455)\end{array}$ & $\begin{array}{l}0.149 \\
(0.330)\end{array}$ & $\begin{array}{l}0.666 \\
(0.428)\end{array}$ & $\begin{array}{l}0.366 \\
(0.493)\end{array}$ & $\begin{array}{l}-0.151 \\
(0.523)\end{array}$ \\
\hline College Higher & $\begin{array}{l}0.386 \\
(0.279)\end{array}$ & $\begin{array}{l}0.508 \\
(0.371)\end{array}$ & $\begin{array}{l}0.725 \\
(0.848)\end{array}$ & $\begin{array}{l}0.505^{*} \\
(0.304)\end{array}$ & $\begin{array}{l}0.669 \\
(0.494)\end{array}$ & $\begin{array}{l}0.302 \\
(0.351)\end{array}$ & $\begin{array}{l}0.882^{*} \\
(0.477)\end{array}$ & $\begin{array}{l}0.273 \\
(0.536)\end{array}$ & $\begin{array}{l}-0.241 \\
(0.546)\end{array}$ \\
\hline$\$ 15,000-\$ 29,999$ & $\begin{array}{c}-0.155 \\
(0.127)\end{array}$ & $\begin{array}{l}0.151 \\
(0.266)\end{array}$ & $\begin{array}{l}-0.253 \\
(0.359)\end{array}$ & $\begin{array}{l}-0.128 \\
(0.140)\end{array}$ & $\begin{array}{l}0.025 \\
(0.271)\end{array}$ & $\begin{array}{l}-0.243 \\
(0.148)\end{array}$ & $\begin{array}{l}-0.362^{*} \\
(0.215)\end{array}$ & $\begin{array}{l}0.207 \\
(0.265)\end{array}$ & $\begin{array}{l}-0.084 \\
(0.222)\end{array}$ \\
\hline$\$ 30,000-\$ 44,999$ & $\begin{array}{l}-0.310^{*} \\
(0.170)\end{array}$ & $\begin{array}{l}0.782 \\
(0.550)\end{array}$ & $\begin{array}{l}-0.248 \\
(0.439)\end{array}$ & $\begin{array}{l}-0.307 \\
(0.189)\end{array}$ & $\begin{array}{l}-0.097 \\
(0.299)\end{array}$ & $\begin{array}{l}-0.427^{*} \\
(0.220)\end{array}$ & $\begin{array}{l}-0.823 * * \\
(0.333)\end{array}$ & $\begin{array}{l}0.196 \\
(0.303)\end{array}$ & $\begin{array}{l}-0.402 \\
(0.313)\end{array}$ \\
\hline$>\$ 45,000$ & $\begin{array}{l}-0.437 \\
(0.297)\end{array}$ & $\begin{array}{l}-11.724 \\
(535.412)\end{array}$ & $\begin{array}{l}-0.548 \\
(0.808)\end{array}$ & $\begin{array}{l}-0.470 \\
(0.332)\end{array}$ & $\begin{array}{l}-0.070 \\
(0.401)\end{array}$ & $\begin{array}{l}-0.943 \\
(0.588)\end{array}$ & $\begin{array}{l}-0.402 \\
(0.495)\end{array}$ & $\begin{array}{l}0.040 \\
(0.558)\end{array}$ & $\begin{array}{l}-0.756 \\
(0.606)\end{array}$ \\
\hline Intercept & $\begin{array}{l}-0.462 \\
(0.488)\end{array}$ & $\begin{array}{l}-0.505 \\
(0.692)\end{array}$ & $\begin{array}{l}-0.117 \\
(1.379)\end{array}$ & $\begin{array}{l}-0.574 \\
(0.538)\end{array}$ & $\begin{array}{l}-1.009 \\
(0.843)\end{array}$ & $\begin{array}{l}-0.212 \\
(0.638)\end{array}$ & $\begin{array}{l}0.810 \\
(0.647)\end{array}$ & $\begin{array}{l}-1.498^{*} \\
(0.822)\end{array}$ & $\begin{array}{l}0.875 \\
(0.684)\end{array}$ \\
\hline $\mathrm{N}$ & 2706 & 1170 & 534 & 2172 & 883 & 1823 & 856 & 648 & 1128 \\
\hline Log Likelihood & -1119.032 & -458.025 & -161.834 & -930.779 & -338.872 & -761.031 & -353.095 & -287.649 & -405.450 \\
\hline Akaike Inf. Crit. & 2316.065 & 994.051 & 399.668 & 1937.557 & 753.743 & 1590.062 & 778.190 & 647.297 & 882.901 \\
\hline
\end{tabular}

Notes: coefficients are marginal effects. Standard errors are in the parentheses. $* * *$, and $* * *$ indicate significance levels at $0.5,0.1$ and 0.01 , respectively

Fig. 1 Marginal Effects Across Different Models: Full Sample
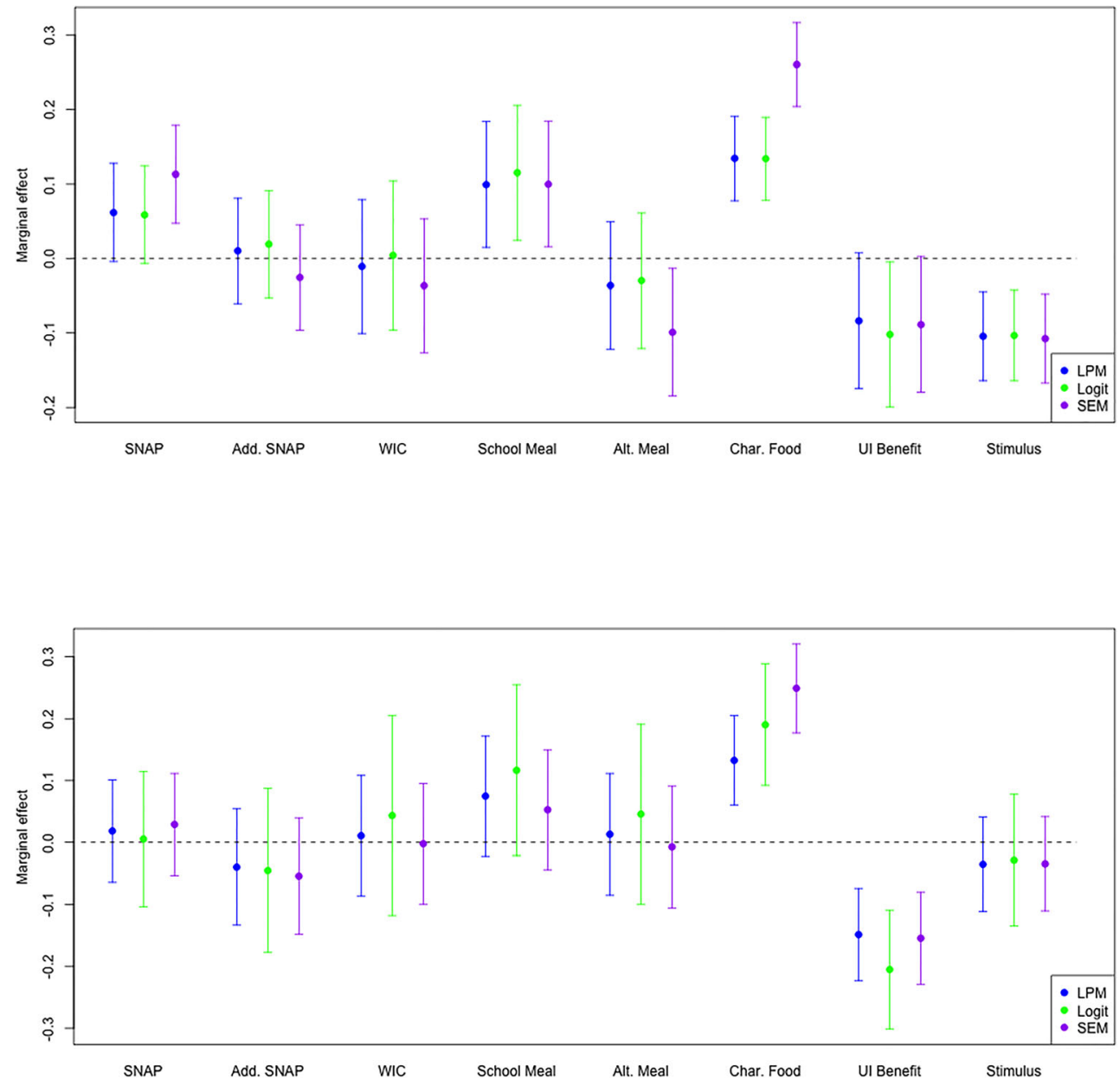

Fig. 2 Marginal Effects Across Different Models: SNAP Eligible 
Fig. 3 Marginal Effects Across Different Models: Lost Job

Fig. 4 Marginal Effects Across Different Models: Has Job

Fig. 5 Marginal Effects Across Different Models: Household with Children
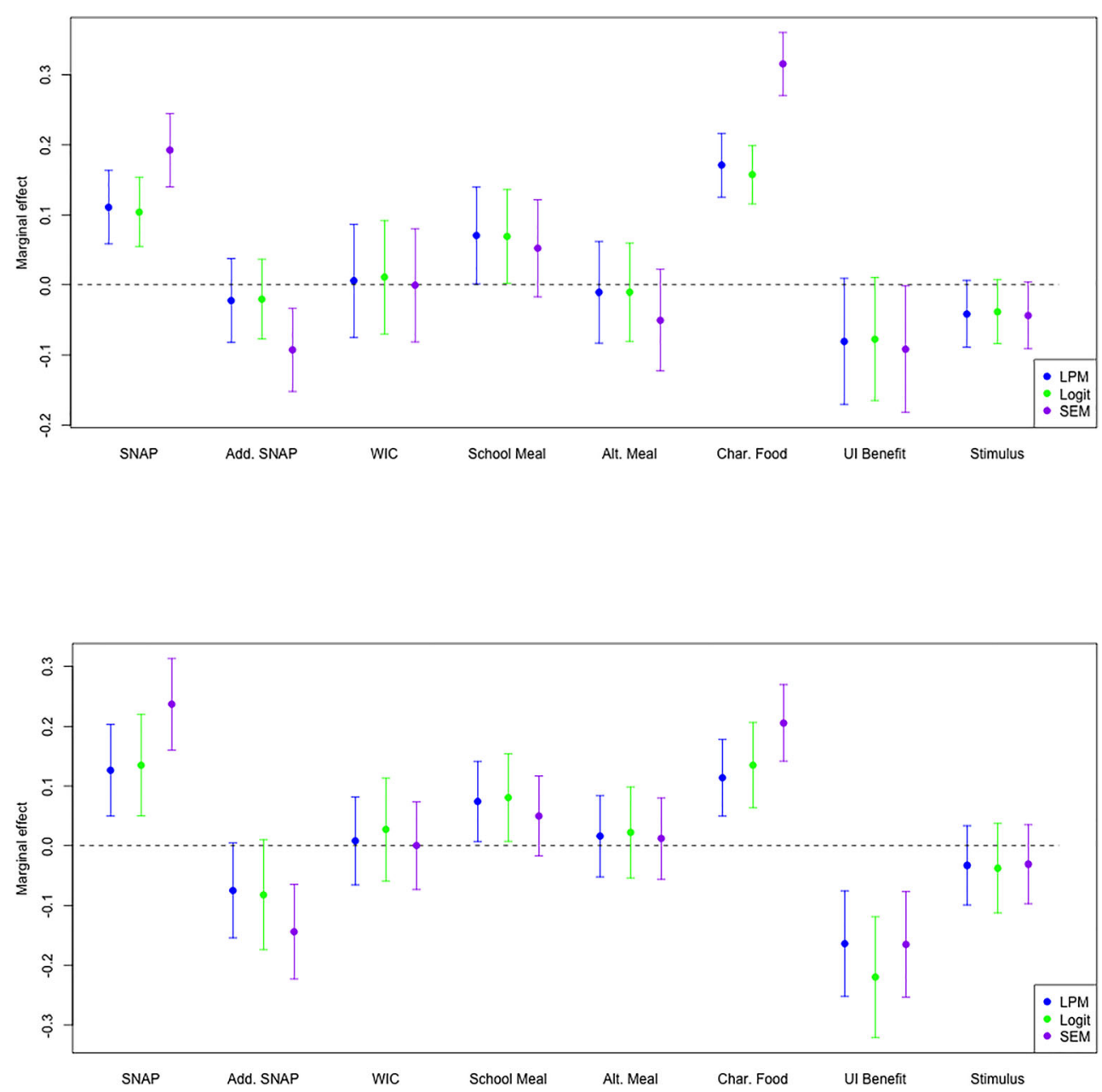
Fig. 6 Marginal Effects Across Different Models: Household without Children

Fig. 7 Marginal Effects Across Different Models: Black Sample

Fig. 8 Marginal Effects Across Different Models: Hispanic Sample
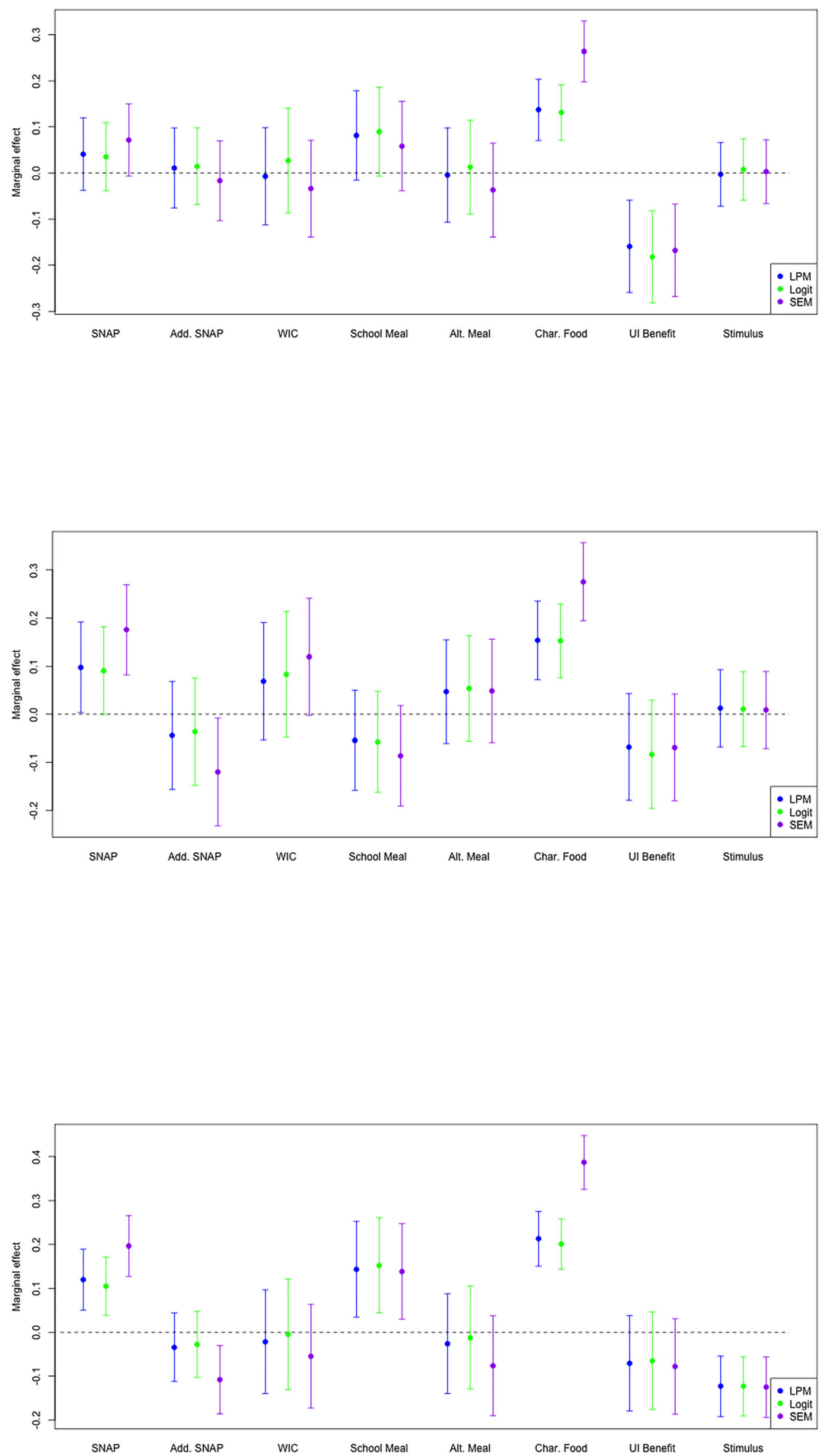
Fig. 9 Marginal Effects Across Different Models: White Sample

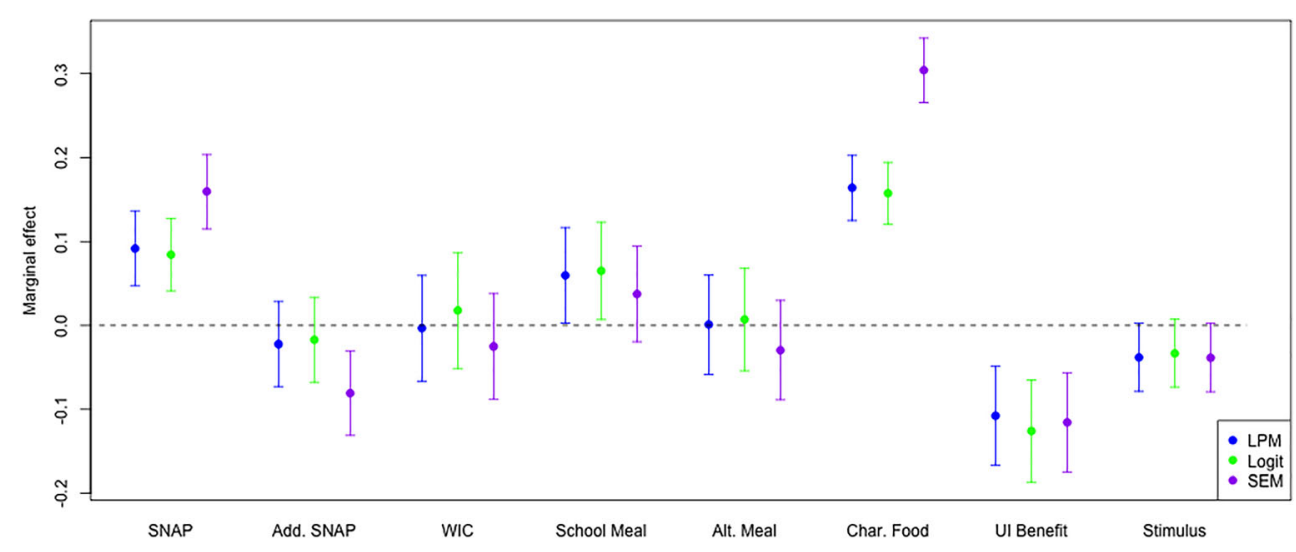

Author contributions Fang: Conceptualization; Formal analysis; Writing - original draft; Writing - review \& editing.

Thomsen: Conceptualization; Writing - original draft; Writing - review \& editing.

Nayga Jr.: Conceptualization; Writing - review \& editing.

Yang: Data curation.

Data availability available.

\section{Declarations}

Conflict of interest The authors declared that they have no conflict of interest.

\section{References}

Bartfeld, J., \& Dunifon, R. (2006). State-level predictors of food insecurity among households with children. Journal of Policy Analysis and Management, 25(4), 921-942.

Bitler, M., \& Hoynes, H. (2016). The more things change, the more they stay the same? The safety net and poverty in the great recession. Journal of Labor Economics, 34(S1), S403-S444.

Bitler, M., Hoynes, H. W., \& Schanzenbach, D. W. (2020). The social safety net in the wake of covid-19. BPEA conference drafts. Brookings papers on economic activity. Retrieved Aug 20, 2020, from https://www.brookings.edu/wp-content/uploads/2020/06/ Bitler-et- al-conference-draft.pdf.

Cannuscio, C. C., Tappe, K., Hillier, A., Buttenheim, A., Karpyn, A., \& Glanz, K. (2013). Urban food environments and residents' shopping behaviors. American Journal of Preventive Medicine, 45(5), 606614.

Chang, H. H., \& Meyerhoefer, C. D. (2020). COVID-19 and the demand for online food shopping services: Empirical evidence from Taiwan. American Journal of Agricultural Economics., 103, 448-465. https://doi.org/10.1111/ajae.12170.
Coleman-Jensen, A., Rabbitt, M., Gregory, C., \& Singh, A. (2019). Household food security in the United States in 2018. USDA-ERS Economic Research Report, 270, 1-35.

Cotti, C. D., Gordanier, J. M., \& Ozturk, O. D. (2020). Hunger pains? SNAP timing and emergency room visits. Journal of Health Economics, 71, 102313.

Dunn, C. G., Kenney, E., Fleischhacker, S. E., \& Bleich, S. N. (2020). Feeding low-income children during the covid-19 pandemic. New England journal of medicine, 382 (18), https://doi.org/10.1056/ NEJMp2005638, e40.

Fitzpatrick, K., Greenhalgh-Stanley, N., \& Ver Ploeg, M. (2016). The impact of food deserts on food insufficiency and SNAP participation among the elderly. American Journal of Agricultural Economics, 98(1), 19-40.

Food Environment Atlas (2020). USDA-ERS. Retrieved Aug 20, 2020 from https://www.ers.usda.gov/data-products/food-environmentatlas/

Gallagher, D., \& Kirkland, P. (April 27, 2020). Meat processing plants across the US are closing due to the pandemic. Will consumers feel the impact. CNN business. Retrieved Aug 20, 2020, from https:// www.cnn.com/2020/04/26/business/meat-processing-plantscoronavirus/index.html

Ganong, P., Noel, P., \& Vavra, J. (2020). US unemployment insurance replacement rates during the pandemic. Journal of Public Economics, 191, 104273.

Greene, W. H. (2008). The econometric approach to efficiency analysis. The measurement of productive efficiency and productivity growth, 1(1), 92-250.

Gregory, C. A., \& Todd, J. E. (2021). SNAP timing and food insecurity. PLoS One, 16(2), e0246946.

Grose, J. (2020). Families scramble to find baby formula, diapers and wipes. New York Times. Retrieved Aug 20, 2020, from https:// www.nytimes.com/2020/03/30/parenting/coronavirus-babyformula-shortages-wipes-diapers.html

Gundersen, C., \& Ziliak, J. P. (2015). Food insecurity and health outcomes. Health Affairs, 34(11), 1830-1839.

Henningsen, A., Hamann, J. D., et al. (2007). Systemfit: A package for estimating systems of simultaneous equations in R. Journal of Statistical Software, 23(4), 1-40. 
Information Resources, Inc. (March 25, 2020). Then and now: Consumer CPG behavior during economic downturns. Retrieved Aug 20, 2020 from: https://www.iriworldwide.com/IRI/media/Library/ COVID-19-Thought-Leadership-3-25-2020.pdf

Johansson, R. (May 28, 2020). Another look at availability and prices of food amid the covid- 19 pandemic. USDA. Retrieved Aug 20, 2020 from https://www.usda.gov/media/blog/2020/05/28/another-lookavailability-and-prices-food-amid-covid-19-pandemic

Nichols, A., \& Simms, M. (2012). racial and ethnic Differences in receipt of unemployment insurance benefits during the Great recession. Unemployment and Recovery Project Brief, 4.

Raifman, J., Bor, J., \& Venkataramani, A. (2021). Association between receipt of unemployment insurance and food insecurity among people who lost employment during the COVID-19 pandemic in the United States. JAMA Network Open, 4(1), e2035884-e2035884.

Ratcliffe, C., \& McKernan, S. M. (2010). How much does SNAP reduce food insecurity? (no. 2239-2019-2874). Retreived march 17, 2021 from https://ageconsearch.umn.edu/record/292080/.

Reardon, T., Belton, B., Liverpool-Tasie, L. S. O., Lu, L., Nuthalapati, C. S., Tasie, O., \& Zilberman, D. (2021). E-commerce's fast-tracking diffusion and adaptation in developing countries. Applied Economic Perspectives and Policy. https://doi.org/10.1002/aepp.13160.

Redman, R. (2020). Online grocery sales to grow $40 \%$ in 2020. supermarket news. Retrieved Aug 20, 2020 from https://www. supermarketnews.com/online-retail/online-grocery-sales-grow-402020

Rosenbaum, D. (2021). Food assistance in president Biden's COVID relief plan would reduce hardship, Provide Economic Stimulus. Center on budget and policy priorities. Retrieved March 17, 2021, from https://www.cbpp.org/research/food-assistance/foodassistance-in-president-bidens-covid-relief-plan-would-reduce

Rosenbaum, D., Bolen, E., Neuberger, Z., \& Dean, S. (2020). States must act swiftly to deliver food assistance allowed by families first act. Center on budget and policy priorities. Retrieved Aug 20, 2020 from https://www.cbpp.org/research/food-assistance/states-are-usingmuch-needed-temporary-flexibility-in-snap-to-respond-to

Siddiqi, S. M., Cantor, J., Dubowitz, T., Richardson, A., Stapleton, P. A., \& Katz, Y. (March 31, 2020). Food access: Challenges and solutions brought on by covid-19. Rand Corporation. Retrieved Aug 20, 2020 from https://www.rand.org/blog/2020/03/food-access-challengesand-solutions-brought-on-by.html

Smith, T. A. (2017). Do school food programs improve child dietary quality? American Journal of Agricultural Economics, 99(2), 339356.

Stone, C. (2020). Cares act measures strengthening unemployment insurance should continue while need remains. CBPP. Retrieved Aug 20, 2020 from https :// www. cbpp. org/ research / federalbudget/cares-act-measures-strengthening-unemploymentinsurance- should-continue

US Department of Labor. (2020). Families first coronavirus response act. Retrieved Aug 20, 2020 from https:/www.dol.gov/agencies/whd/ pandemic/ffcra-employee-paid-leave

US Department of the Treasury. (2020). The cares act works for all Americans. Retrieved Aug 20, 2020 from https://home.treasury. gov/policy-issues/cares.

USDA-ERS (2020) Food Security in the US: Key Statistics \& Graphics. Retrieved Aug 20, 2020 from https://www.ers.usda.gov/topics/ food-nutrition-assistance/food-security-in-the-us/key-statisticsgraphics.aspx
USDA-FNS. (2020a). Supplemental nutrition assistance program (SNAP). Retrieved Aug 20, 2020 from https://www.fns.usda.gov/ snap/supplemental-nutrition-assistance-program

USDA-FNS. (2020b). Child and adult care food program. Retrieved Aug 20, 2020 from https://www.fns.usda.gov/cacfp.

USDA-FNS. (2020c). Special supplemental nutrition program for women, infants, and children (WIC). Retrieved Aug 20, 2020 from https://www.fns.usda.gov/wic

USDA-FNS. (2020d). FNS launches the online purchasing pilot. Retrieved Aug 20, 2020 from https://www.fns.usda.gov/snap/ online-purchasing-pilot

USDA-FNS. (2020e). U.S. Adult Food Security Survey Module. Retrieved Aug 20, 2020 from https://www.ers.usda.gov/topics/ food-nutrition-assistance/food-security-in-the-us/survey-tools/ f.

Wilde, P. E., \& Ranney, C. K. (2000). The monthly food stamp cycle: Shopping frequency and food intake decisions in an endogenous switching regression framework. American Journal of Agricultural Economics, 82(1), 200-213.

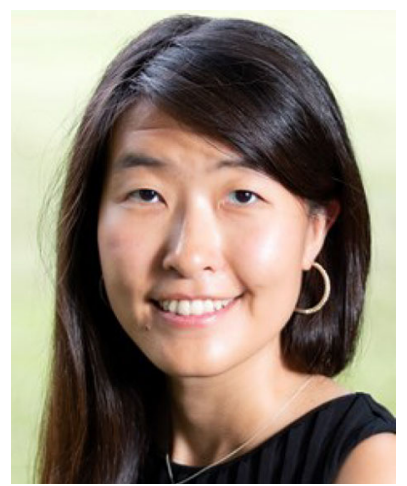

Di Fang is Assistant Professor in the Department of Agricultural Economics and Agribusiness at the University of Arkansas. She received a $\mathrm{Ph} . \mathrm{D}$. in Business Administration (Agribusiness) from W.P. Carey School of Business at Arizona State University. Dr. Fang's research focus on food and health economics, consumer economics and marketing, and issues related to childhood obesity.

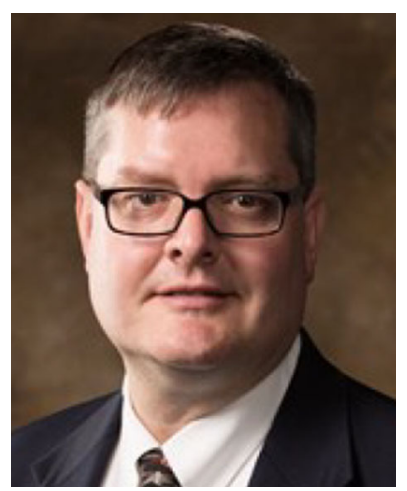

Michael Thomsen is Professor and Governor Sidney S. McMath Endowed Chair in Obesity Prevention. He is in the Department of Health Policy and Management, Fay W. Boozman College of Public Health, University of Arkansas for Medical Sciences. He completed his $\mathrm{PhD}$ at the University of Minnesota in agricultural and applied economics with a minor in business administration. Dr. Thomsen's research program emphasizes linkages between the food marketing system and human health. Topic areas include the effect of the commercial food environment on childhood obesity and the economics of nutrition programs. 


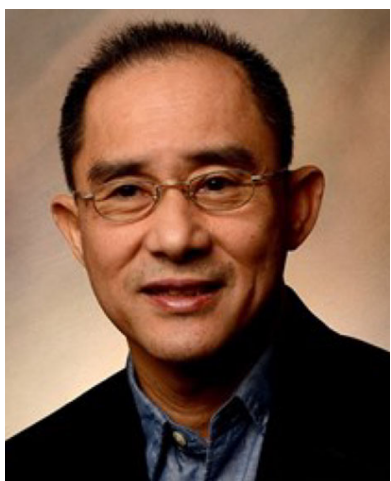

Rodolfo M. Nayga , Jr. is Professor and Head, Department of Agricultural Economics at Texas A\&M University. He received his Ph.D. from Texas A\&M University. His research interests are focused on the economics of food policy and quality and on obtaining an understanding of how emerging consumer issues affect food and nutrient consumption/demand, obesity, and public policies.

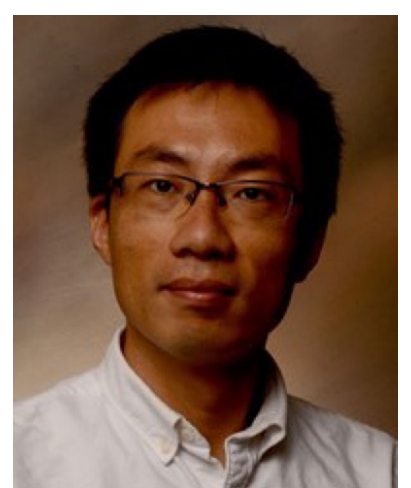

Wei Yang is a program associate in the Department of Agricultural Economics and Agribusiness at the University of Arkansas. He received M.S. degrees in Agricultural Economics and Statistics. His specialties are experimental design and data analysis of choice experiment. 